\title{
Türk D1ş Politikası Krizlerinde Hükümetler, Cumhurbaşkanları ve Başbakanlar
}

\author{
Governments, Presidents and Prime Ministers in Turkey's
}

Foreign Policy Crises

\section{Fuat AKSU}

Doç. Dr., Siyaset Bilimi ve Uluslararası İlişkiler Bölümü, Yıldız Teknik Üniversitesi

\section{Bu makaleye atıf için}

Aksu, Fuat, "Türk D1ş Politikası Krizlerinde Hükümetler, Cumhurbaşkanları ve Başbakanlar", Uluslararası İlişkiler, Cilt 13, Say1 59, 2018, s. 65-87, DOI: 10.33458/uidergisi.523830

Makaleye Erişim İçin: https://dx.doi.org/10.33458/uidergisi.523830

Makale Gönderim: 05 Nisan 2018

Basım Tarihi: 01 Eylül 2018

\section{Uluslararası İlişkiler Konseyi Derneği | Uluslararası İlişkiler E-Posta: bilgi@uidergisi.com.tr}

Bu makalenin tüm hakları Uluslararası İişkiler Konseyi Derneğìne aittir. Önceden yazılı izin almadan hiçbir iletişim, kopyalama ya da yayın sistemi kullanılarak yeniden yayımlanamaz, çoğaltılamaz, dağıtılamaz, satılamaz veya herhangi bir ssekilde kamunun ücretli/ücretsiz kullanımına sunulamaz. Akademik amaçlı alıntılar bu kuralın dışındadır. Yazıda belirtilen fikirler yalnızca yazarına/yazarlarına aittir. UİK Derneğini, editörleri ve diğer yazarları bağlamaz. 


\title{
Türk Dış Politikası Krizlerinde Hükümetler, Cumhurbaşkanları ve Başbakanlar
}

\author{
Fuat AKSU \\ Doç. Dr., Siyaset Bilimi ve Uluslararası İlişkiler Bölümü, Yıldız Teknik Üniversitesi, İstanbul. \\ E-posta:faksu@yildiz.edu.tr
}

Bu makale TÜBİTAK 1001 projesi (Proje No.: 112K172) desteğiyle hazırlanmıştır.

Değerlendirme ve katkılarından dolayı hakemlere ve editoryal ekibe teşekkür ederim.

\begin{abstract}
ÖZET
Bu çalş̧mada Türkiyennin dış politika krizlerinde karar alma süreci ve karar biriminin etkisi analiz edilmektedir. Türkiye’de 36 dış politika krizinde karar biriminin rolü hükümetin çoğunluk veya koalisyon şeklinde olmasına bağlı olarak değişkenlik gösterir. Dış politika krizlerinde yürütme erkinde cumhurbaşkanı ve başbakanın nihai karar birimi olarak üstelendikleri roller dış politika karar sürecini şekillendirir. Siyasal sorumluluğu bulunmayan cumhurbaşkanlarının görüş ifade etmenin ötesine geçerek nihai karar birimi olmaya çalışmaları dış politika krizlerinin yönetimini zorlaştırmaktadır. Parlamenter demokrasilerde yürütme ve yasama arasındaki denge siyasal sorumlu olanın denetlenebilirliğine dayalıdır. Böylece krizlere ilişkin kararlarda karar yapı ve süreci içerisindeki tüm aktörlerin uyumlu işbirliği kriz yönetiminin başarısını arttırmaktadır.
\end{abstract}

Anahtar Kelimeler: Dış Politika Krizi, Karar Birimi, Kriz Yönetimi, Türk Dış Politikası

\section{Governments, Presidents and Prime Ministers in Turkey's Foreign Policy Crises}

\begin{abstract}
This study investigates Turkey's decision making process during foreing policy crises in order to analyse what impact and roles the decision units have in crisis management. In 36 foreign policy crises, the role of decision units in the final decisions varies according to whether the government in power is a majority or coalition government. The decision making process during foreign policy crises is shaped by the role of the president and the prime minister as the ultimate decision units within the executive. The attempts by presidents to go beyond making statements and to become the ultimate decision maker in foreign policy crises, despite being unaccountable in political terms, is a factor that further complicates crisis management. In parliamentary democracies, the balance between the executive and legislative relies on the accountability of those having political responsibility. Thus, the harmonious copoeration of all actors in the structure and process of decision making at times of process increases the success of crisis management.
\end{abstract}

Keywords: Foreign Policy, Decision Unit, Crisis Management, Turkish Foreign Policy 


\section{Giriş}

Uluslararası ilişkilerde krizler istisnai durum değişikliği olarak kabul edilebilir. Devletlerin aralarındaki uyuşmazlıkları diplomasi, siyasi araç ve yöntemlerden yararlanarak, çatışma ve savaşa varmadan çözmeleri beklenir. Beklentiye rağmen uyuşmazlık ve çatışmalar krizlere, sınırlı ve/veya topyekûn savaşlara dönüşebilir. Genel ifadesiyle kriz otonom davranabilme yeteneğine sahip aktörün karşılaştı̆̆ durumsal değişiklik sırasında tehditlerle tercihleri ve kapasitesi arasında bir denge kurmakta zorlanmasını ifade eder. Karar birimi, tehdit karşısında elindeki avantajlarını koruyabilmiş, herhangi bir kayba uğramadan, askeri çatışmaya girmeden süreçten çıkabilmişse kriz yönetiminde başarılıdır.

Devletler arası ilişkiler açısından krizin tanımı görece daha karmaşıktır. Örneğin Charles Hermann krizi tanımlarken üç özelliğini ön plana çıkartmaktadır; kriz olarak tanımlanan durumsal değişiklik yüksek önceliklere bir tehdit oluşturmalı, aniden ortaya çıkmalı ve sürpriz olarak değerlendirilmeli, karar birimini kısa zaman diliminde tepki vermeye zorlamalıdır. ${ }^{1}$ Bir krizde bu üç özelliği bir arada bulmak zor olsa da karar birimi bu durumsal değişikliği "kriz” olarak kabul edebilir.

Michael Brecher ise çalışmalarında bu tanımlamayı geliştirerek bir durumsal değiş̧ikliğin "kriz" olarak tanımlanabilmesi için ani, sürpriz niteliğinin olmasının gerekli olmadığını söyler. Hermann'dan farklı olarak "yüksek değerler"e yönelik tehdit yerine "temel değer ve öncelikler"e yönelik tehditten yola çıkarak krizin tarafları arasındaki ilişkilerde hasmane tutumun, düşmanlığın normalden daha fazla gözlenebilir olmasına işaret eder. Brecher’a göre bu durumsal değişiklik karar birimini “kısa zaman”da değil "kısıtlı zaman" diliminde tercih yapmaya zorluyor ise krizden söz edilebilir. ${ }^{2}$

Bir başka çalışma ise dış politika krizini tanımlarken aşağıdaki parametrelerin varlığına işaret etmektedir:

... krizin tetikleyicisi olarak kabul edilen gelişme;

- Karar alıcının dış politika gündemini meşgul edebilecek herhangi bir konuda ortaya çıar,

- Zamanlama bakımından aniden ortaya çıar veya belli bir zaman dilimi içerisinde gelişir,

- Karar alıcının algısında ve/ya gerçekliğinde temel değer ve önceliklerinde bir değişiklik yapmaya zorlar,

- Bu durum karar alıcı bakımından risk, tehlike, tehdit veya saldırı olarak algılanır,

- Bu algısal durum dolayısıyla karar alıcı mevcut kısıtlı seçenekler arasında bir tercih yapmak ve karar almak zorundadır,

- Karar alıcının alacağı karar dolayısıyla doğrudan muhatabı olan aktör ve/ya aktörlerle bir askeri çarpışma-savaşa girme olasılı̆̆ı bulunmakla birlikte bu durum her zaman ortaya çımaz. ${ }^{3}$

Bu tanım Hermann ve Brecher'ın tanımlarının esnek bir bileşkesidir ve askeri-siyasi krizlerin dışındaki krizleri de analiz edebilmek mümkündür. Karar biriminin algısında veya gerçekliğinde

1 Charles Hermann, "International Crisis as a Situational Variable", James N. Rosenau (der.), International Politics and Foreign Policy, New York, Free Press, 1969, s.409-421.

2 Bkz. Michael Brecher, Crises in World Politics: Theory and Reality, Oxford, Pergamon Press, 1993; Michael Brecher, International Political Earthquakes, Ann Arbor, University of Michigan Press, 2008.

3 Bkz. Fuat Aksu, Türk Dış Politikasında Karar Alma ve Kriz Yönetimi Süreç Analizi, İstanbul, Dış Politika ve Kriz İncelemeleri Yay., 2017, s.31-32. 
durumsal değişikliğin yaratmış olduğu (risk, tehlike, tehdit ve saldırıya) etkiye göre krizi tanımlama olanağı verdiği için Türkiye'nin dış politika krizlerinden bazılarını tek taraflı veya iki taraflı kriz olarak tanımlamaya olanak vermektedir.

Çalışmada Cumhuriyet döneminde Türkiye’nin dış politika krizlerinde karar ve kriz yönetim süreçlerinin nasıl işlediği araştırılacaktır. Bu çerçevede nihai karar birimi olarak başbakan ve/ya cumhurbaşkanının kriz yönetim sürecinde üstlendiği rollerin krizleri nasıl etkilediği tartışılacaktır. Türkiye'deki yasal-bürokratik yapı ve kurulan hükümetlerin çoğunluk veya koalisyon hükümetleri olmasının kriz anındaki kararların oluşumunda nasıl bir etkisi yaratmış olduğu analiz edilecektir. Böylece Türkiye'nin Cumhuriyet dönemi dış politika krizlerinde hükümetlerin, cumhurbaşkanları ve başbakanların kararlarında nasıl bir farklılaşmanın/benzerliğin olduğu anlaşılabilecektir.

Çalışmanın kurgusu bakımından karar birimi, yapısı ve sürecine ilişkin bir analizde kriz anındaki uluslararası sistem koşullarındaki değişimi de dikkate almak gerekir. Bu açıdan ampirik verilerin kullanılacağı çalışmada neoklasik realizmin dış politika kararlarının oluşumunda önermiş olduğu değişkenler modellemesi uygun bir analiz çerçevesi oluşturacaktır. ${ }^{4}$ Çünkü kriz anındaki sistemsel koşullar ve uluslararası-bölgesel gündemin kısıtları [bağımsız değişkenler], içyapısal özellikler, gündem ve materyal güç kapasitesinin yanı sıra doğrudan siyasal karar biriminin liderlik özellikleri [müdahil değişkenler] dış politikayı [bağımlı değişken] şekillendirir. ${ }^{5}$ Bir başka ifadeyle siyasal karar birimi krize ilişkin kararını oluştururken uluslararası sistemin etkisiyle beraber kendi ulusal özelliklerini, gündemini de dikkate alır. Gerçekte siyasal bakımdan bu görev, yetki ve sorumluluğa sahip karar birimi dış ile içi uyumlulaştırırken aynı zamanda kendi çıkar ve önceliklerini de dikkate alabilmektedir.

$\mathrm{Bu}$ açıdan Cumhuriyet döneminde üç temel uluslararası sistemin etkisi dikkate alınarak Soğuk Savaş öncesi dönemde (1923-1945) 7, Soğuk Savaş döneminde (1945-1991) 15, Soğuk Savaş ardılı dönemde (1991 sonrası) ise 15 'in üzerinde dış politika krizi yönetilmiştir. ${ }^{6}$ Söz konusu krizlerde karar birimleri mevcut sistemde baskın uluslararası aktörlerin tepkilerini dikkate alarak krizlerdeki tercihlerini şekillendirmiştir. Ancak bu çalışmada bağımsız değişken olarak kriz anlarındaki sistemsel etki yerine siyasi sorumlu karar birimine ve karar yapısına odaklanılacaktır. ${ }^{7}$ Daha açık bir ifadeyle çalışmada neoklasik realizmin müdahil değişken olarak kabul ettiği siyasal karar birimi ve iç kısıtlardaki değişikliklerin ve yapısal özelliklerin farklı krizlerde nasıl bir özellik sergilediği tartışılacaktır.

4 Bkz. Aksu, Ibid. Ayrıca bkz. Gideon Rose, "Neoclassical Realism and Theories of Foreign Policy”, World Politics, Cilt 51, No.1, Ekim 1998, s.144-172.

5 Balkan Devlen ve Özgür Özdamar, "Neoclassical Realism and Foreign Policy Crises”, A. Freyberg-Inan, E.Harrison and P.James (der.), Rethinking Realism in International Relations: Between Tradition and Innovation, Baltimore, The Johns Hopkins University Press, 2009, s.136-164.

6 Bkz. TFPC Projesi sonuçları, www.tdpkrizleri.org (Erişim Tarihi 4 Eylül 2018).

7 Kriz yönetimi-analizi açısından çoğu kez krizin tetiklendiği andan itibaren mevcut sistem koşullarının kriz yönetim süreçlerinde etkisi dikkate alınır. Her özgün krizin tetiklendiği anda karar birimi sistemsel ve iç etkileri dikkate alarak krize ilişkin kararı oluşturur. Dolayısıyla, kriz yönetimi ve analizi açısından sistemsel yapının genel özellikleri değil, tam aksine karar anındaki durumu dikkate alınır. Nitekim örneğin 1964 Johnson Mektubu Krizi’nde Türkiye'nin Kıbrıs'a ilişkin kararına sert tepki gösteren ABD’nin (ve SSCB’nin) müdahilliği ile 1964 ve 1967 Kıbrıs krizlerindeki etkisi çok farklıdır. Benzer şekilde, 1990 sonrasında örneğin Nahcivan Krizi’nde Türkiye, hem sistemsel ve bölgesel koşulları hem de Rusya Federasyonu’nun, ABD’nin ve AB'nin sürece müdahilliğini dikkate alarak krize ilişkin kararlarını oluşturmuştur. 


\section{Türkiye'nin Taraf Olduğu Dış Politika Krizleri}

Dış politika krizlerini araştıran International Crisis Behavior Project'de (ICB/ICBP) Türkiye'nin tarafı olduğu krizlerin sayısı görece sınırlıdır. Turkish Foreign Policy Crises (TFPC) Projesindeki dış politika krizlerinin sayısı ise 2017 yılı itibariyle 36'dır ve insani, hukuki nitelikteki krizleri de içermektedir (Bakınız Tablo 1). ${ }^{8}$

\begin{tabular}{|c|c|c|c|c|}
\hline & $\begin{array}{c}\text { Tablo 1: ICB Projesi-TFPC Projesi D } \\
\text { Türk Dış Politikası Krì İncelemeleri Projesi'nde Türkiye'nin } \\
\text { Doğrudan Taraf Olduğu Dıș Politika Krizleri }\end{array}$ & $\begin{array}{l}\text { Iş Politika Krizleri Türkiye Karşılaştırması } \\
\text { International Crisis Behavior Project'de Türkiye'nin } \\
\text { Doğrudan Taraf Olduğu Dış Politika Krizleri }\end{array}$ & & \\
\hline YILLAR & TFPC'DEKİ ADI & ICBP'DEKI ADI & TFPC & ICBP \\
\hline 1919 & - & CILICIAN WAR (1919) & - & $\checkmark$ \\
\hline 1920 & - & GREECE-TURKEY WAR I (1920) & - & $\checkmark$ \\
\hline 1921 & - & GREECE-TURKEY WAR II (1921) & - & $\checkmark$ \\
\hline 1922 & - & CHANAK (1922) & - & $\checkmark$ \\
\hline 1924 & MUSUL KRİZI & MOSUL LAND DISPUTE (1924) & $\checkmark$ & $\checkmark$ \\
\hline 1926 & BOZKURT LOTUS KRİZI & - & $\checkmark$ & - \\
\hline 1929 & KÜÇÜK AĞRI KRİZI & - & $\checkmark$ & - \\
\hline 1935 & BULGARISTAN KRİZI & BULGARIA-TURKEY (1935) & $\checkmark$ & $\checkmark$ \\
\hline 1936 & SANCAK KRİZI & ALEXANDRETTA (1936) & $\checkmark$ & $\checkmark$ \\
\hline 1940 & - & BALKAN INVASION (1940) & - & $\checkmark$ \\
\hline 1942 & STRUMA KRİZI & - & $\checkmark$ & - \\
\hline 1945 & SOVYET TALEPLERİ KRİZI & KARS-ARDAHAN (1945)* & $\checkmark$ & $\checkmark$ \\
\hline 1946 & - & TURKISH STRAITS $(1946)^{*}$ & - & $\checkmark$ \\
\hline 1947 & - & TRUMAN DOCTRINE (1947) & - & $\checkmark$ \\
\hline 1955 & 6-7 EYLÜL OLAYLARI KRİZI & - & $\checkmark$ & - \\
\hline 1957 & SURIYY KRIZİ & SYRIA-TURKEY CONFRONTATION (1957) & $\checkmark$ & $\checkmark$ \\
\hline 1958 & IRAK KRİZI & - & $\checkmark$ & - \\
\hline $1963-64$ & KIBRIS KRİZI & CYPRUS I (1963) & $\checkmark$ & $\checkmark$ \\
\hline 1964 & JOHNSON (MEKTUBU) KRİZI & - & $\checkmark$ & - \\
\hline 1967 & KIBRIS KRİZI & CYPRUS II (1967) & $\checkmark$ & $\checkmark$ \\
\hline $1972-73$ & AFYON EKİMİ KRİZI & - & $\checkmark$ & - \\
\hline 1974 & KIBRIS (ENOSIS) KRİZI & CYPRUS III (1974) & $\checkmark$ & $\checkmark$ \\
\hline $1974-1980$ & EGE DENIZİ (NOTAM-FIR) KRİZI & - & $\checkmark$ & - \\
\hline 1974-1976 & EGE DENIZII (KITA SAHANLIĞI) KRİZI & AEGEAN SEA I (1976) & $\checkmark$ & $\checkmark$ \\
\hline 1981 & LIMNI KRİZI & - & $\checkmark$ & - \\
\hline 1984 & - & AEGEAN SEA II (1984) & - & $\checkmark$ \\
\hline 1984-1990 & BATI TRAKYA OLAYLARI KRIZİ & - & $\checkmark$ & \\
\hline 1987 & EGE DENIZZI (KITA SAHANLIĞI) KRİZI & AEGEAN SEA III (1987) & $\checkmark$ & $\checkmark$ \\
\hline 1988-1991 & IRAKLI KÜRT SIĞINMACILAR KRİZI & - & $\checkmark$ & - \\
\hline 1989 & BULGARISTAN GÖÇ KRİZI & - & $\checkmark$ & - \\
\hline 1992 & ERMENISTAN (NAHÇIVAN) KRİZI & - & $\checkmark$ & - \\
\hline 1992 & TCGMUAVENET KRİZI & - & $\checkmark$ & - \\
\hline 1994 & EGE DENIZİ (casus belli) KRİZI & - & $\checkmark$ & - \\
\hline 1996 & EGE DENIZI (KARDAK/IMIA) KRİZI & AEGEAN SEA IV (1996) & $\checkmark$ & $\checkmark$ \\
\hline 1997 & KIBRIS (S300 FÜZELERI) KRİZI & CYPRUS-TURKEY MISSILE CRISIS (1998) & $\checkmark$ & $\checkmark$ \\
\hline 1998 & SURIYE (ÖCALAN) KRİZI & SYRIA-TURKEY (1998) & $\checkmark$ & $\checkmark$ \\
\hline 2003 & SÜLEYMANIYE BASKINI (ÇUVAL) KRİZI & - & $\checkmark$ & - \\
\hline $2003-$ & DOĞU AKDENIZZ MEB KRİZİ & - & $\checkmark$ & - \\
\hline $2010-$ & MAVİ MARMARA BASKINI KRİZI & - & $\checkmark$ & - \\
\hline 2011- & SURİYE KRİZI & SYRIA-TURKEY BORDER INCIDENTS (2012) & $\checkmark$ & $\checkmark$ \\
\hline 2014 & IȘiD KONSOLOSLUK REHİNE KRIZŻ & - & $\checkmark$ & - \\
\hline 2014- & SÜLEYMAN ȘAH TÜRBESİ KRİZI & - & $\checkmark$ & - \\
\hline 2016- & BAȘİKA KRİZI & & $\checkmark$ & - \\
\hline 2016- & SU-24 UÇAĞININ DÜȘÜRÜLMESİ KRİZI & TURKEY-RUSSIA JET INCIDENT (2015) & $\checkmark$ & $\checkmark$ \\
\hline
\end{tabular}

\section{Dış Politika Krizlerinde Karar[laştırma] ve Siyasal Karar Birimi}

Dış politikaya ilişkin kararlar yürütme erkinin görev, yetki ve sorumluluğundadır. Müdahil değişkenlerden biri olarak karar[laştırma] birimi (decision unit) ${ }^{9}$ siyasal rejimin ve devlet bürokrasisinin oluşumuna göre farklı ve çok sayıda aktörden, kurumdan oluşabilir. Nihai karar biriminin kim ya da

8 Bu konuda bkz. www.tdpkrizleri.org (Erişim Tarihi 4 Eylül 2018).

9 Karar birimi (decision unit) terimi bu çalışmada geniş anlamda ve [nihai] kararın siyasi sorumluluğunu üstlenmiş aktörü tanımlamakta kullanılmaktadır. 
kimler olduğu özellikle krizlerde çok daha önemlidir. ${ }^{10}$ Gündelik işleyişte çoğu kez karar birimi düşük seviyede aktörlerden oluşturulabilirken önem ve aciliyet derecesi yüksek konularda karar birimi üst düzey katılımcılardan oluşturulabilir. ${ }^{11}$ Ayrıca zamana, konunun niteliğine göre devlet bürokrasisinin çeşitli düzeyleri ve birimleri arasında iletişim ve işbirliğine ihtiyaç duyulabilir. Devlet adına karar yetkisine sahip olan "hükümet" in görev, yetki, sorumlulukları ise siyasal rejimin niteliğine göre anayasa ve yasalarda hükme bağlanır. Yürütmeyi temsil eden hükümet yasama önünde bu sorumluluğunu yerine getirirken uygun araç/yöntemlerle denetlenir. Ancak çoğu kez hükümetin yasama karşısında ortak sorumluluğuna rağmen önemli konularda nihai kararda tek bir kişinin tüm yetki ve sorumluluğu üstlenmiş olduğu görülebilir.

Rutin dış politika konularında devletler ilgili temsilcileri aracılığıyla önceden kararlaştırılmış tepkilerini uygularlar. Uyuşmazlık, çatışma ve/ya krizi tetikleyecek gelişmeler karşısında gösterilecek tepkilerse görece farklıdır ve kurumsal-bürokratik hiyerarşi içerisinde yeni direktiflere ihtiyaç gösterir. Özellikle kriz durumlarında nihai karar biriminin kararı devletin resmi görüşü olarak açıklanır ve uygulanır. Ancak kararın oluşumu göründügü kadar kolay gerçekleşmez; anayasal-yasal-kurumsal karar yapısının uyumlu işleyişine ihtiyaç duyulur. Karar yapısında yürütme erkine bağlı çok sayıda resmi (bazen yarı veya gayri-resmi) destekleyici aktör bulunabilir. Açıkça nihai ve siyasi sorumlu karar biriminin yetkilendirmediği hiçbir birim krize ilişkin nihai kararı belirlemeye yetkili değildir. Nihai ve siyasi sorumlu karar birimi Türkiye örneğinde başbakan ve bakanlar kuruludur. ${ }^{12}$ Krizlerde her ne kadar zaman zaman cumhurbaşkanları başbakanlara göre daha baskın rol üstlenseler de anayasal olarak cumhurbaşkanlarının yaptıklarından başbakan ve bakanlar kurulu sorumlu tutulmuştur. ${ }^{13}$

Bununla birlikte, dış politika konusunda karar[laştırma] farklı işleyebilir. Örneğin Hermann ve Hermann’a göre dış politika konusunda karar birimleri üç gruba ayrılabilir: ${ }^{14}$

1. Baskın Lider (Predominant Leader): Tek bir kişi seçim yapma ve olası muhalefeti bastırma gücüne sahiptir.

2. Tek Grup (Single Group): Bireylerden oluşan bir takım; tümü tek bir oluşumun üyeleri. Yüz yüze etkileşim içerisinde kolektif olarak bir hareket tarzı seçer ve bir uyum elde ederler.

3. Çoklu Otonom Aktörler (Multiple Autonomous Actors): Tek başına kararlaştırma ve diğerleri üzerinde zorlama yeteneğine sahip, her biri ayrı hareket edebilen çok sayıda birey, grup ve kurum temsilcisi vardır.

10 Bkz. Margaret G. Hermann ve Charles Hermann, "Who Makes Foreign Policy Decisions and How: An Empirical Inquiry”, International Studies Quarterly, Cilt 33, No.4, Aralık 1989, s.361-387.

11 Hermann ve Hermann'ın vurguladığı gibi herhangi bir konuda nihai karar birimi kamu yönetiminde hiyerarşik olarak daha düşük düzeyde oluşturulabilir. Bununla birlikte hiyerarşinin üst seviyesinde yer alan karar biriminin daha alt seviyedeki karar biriminin kararını değiştirebilmesi teorik olarak mümkündür. Bu ise uygulamada karmaşık sorunlara neden olabilir; örneğin hiyerarşik olarak daha üst düzeyde bulunan karar birimi "nihai karar birimi” olarak belirlenmiş olan alt düzeydeki karar biriminin aldığı kararı hangi durumlarda değiştirebilecektir? Bkz. Hermann ve Hermann, "Who Makes Foreign", s.363.

$12 \mathrm{Bu}$ durum 1961 ve 1982 Anayasalarında böyledir. 16 Nisan 2017 Anayasa değişikliği referandumuyla durum farklılaşmış, Cumhurbaşkanının yürütme erkinin tüm görev, yetki ve sorumluluğunu üstlenmesi hükme bağlanmıştır. “6771 Sayılı Kanun Gereğince Birlikte Yapılan Türkiye Büyük Millet Meclisi ve Cumhurbaşkanlığı Seçimleri Sonucunda Cumhurbaşkanının Göreve Başladığı Tarihte Yürürlüğe Girecek Değişiklikler” için bkz. http://www.anayasa.gov.tr/ icsayfalar/mevzuat/1982anayasas\%C4\%B1.html, (Erişim Tarihi 4 Eylül 2018).

1316 Nisan 2017 tarihli referandumda kabul edilen Anayasa değişikliği ile "Bakanlar Kurulu” ibaresi, 6771 sayılı Kanunun 16 'ncı maddesi ile metinden çıkarılmıştır.

14 Hermann ve Hermann, "Who Makes Foreign”, s.363-364. 
Hermann modellemesine göre Türkiye'de dış politika karar yapısının "baskın lider" odağında oluştuğu görülür. İster başbakan ister cumhurbaşkanı yürütmenin başında nihai-siyasi sorumlu olarak bulunmuş olsun dış politika kararlarında yetkilerini bir başka grup veya aktör ile paylaşmamaktadır. ${ }^{15}$

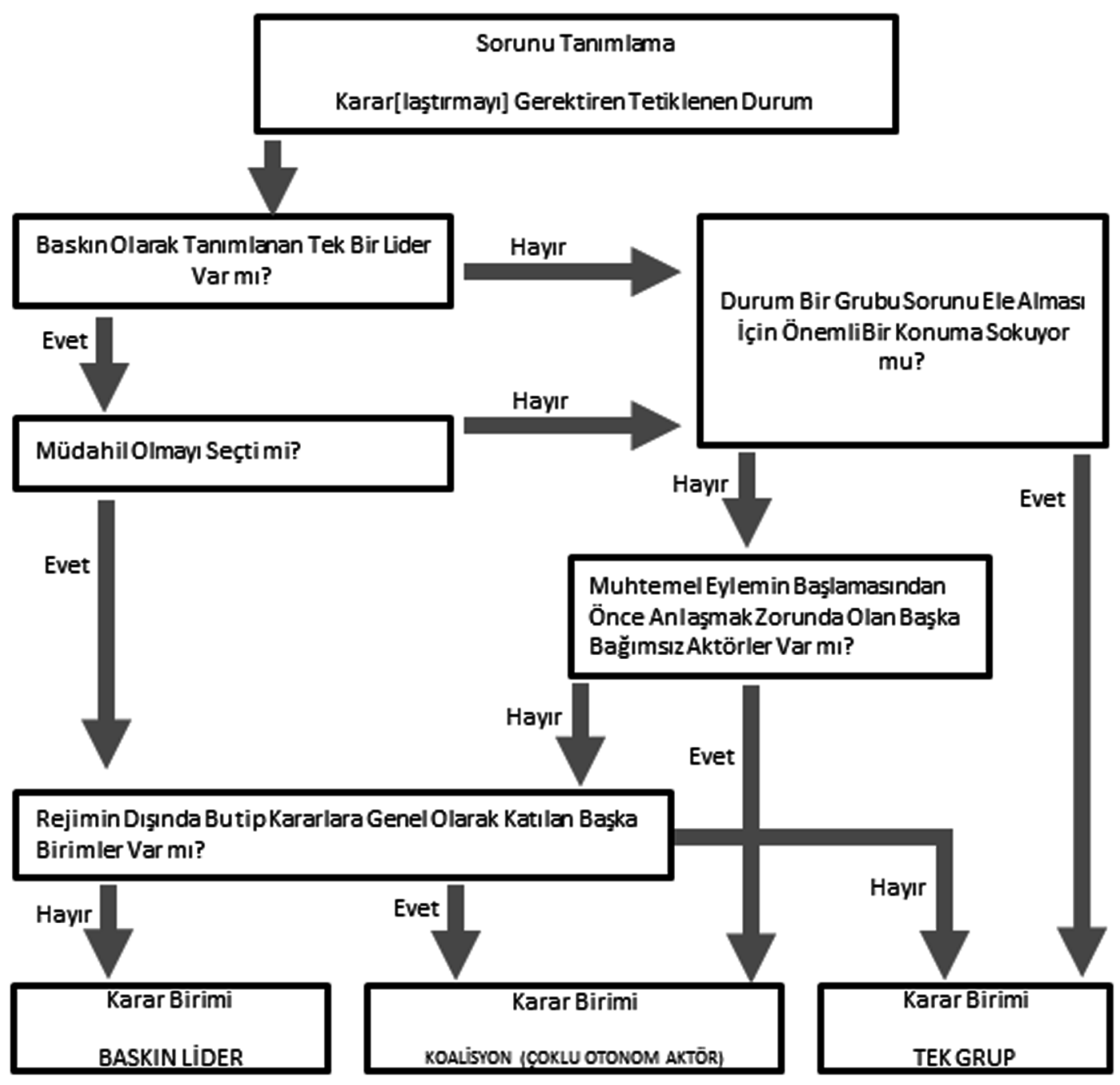

Şekil 1: Karar Birimi Belirleme Süreci

Margaret G. Hermann, "How Decision Units Shape Foreign Policy: A Theoretical Framework", International Studies Review, Cilt 3, No.2, 2001, s.58'den uyarlanmıştır.

15 Ancak Türkiye örneğinde yürütme çoğunluk hükümeti şeklinde olsa da savaş ilanı ve/veya yabancı silahlı kuvvetlerin ülkeye kabulü gibi özel durumlarda yetki ve sorumluluğu yasamayla ortaklaşa kullanmak zorundadır. Bu durumda yürütme ve yasama birer otonom aktör/birim olarak koalisyon halinde kararın oluşumuna katılmaktadır. Bkz. Zeynep Taydaş ve Özgür Özdamar, “A Divided Government, An Ideological Parliament, and An Insecure Leader: Turkey’s Indecision about Joining the Iraq War”, Social Science Quarterly, Cilt 94, No.1, 2013, s.217-241. Bir başka açıdan ele alındığında devlet başkanlarının silahlı kuvvetlere komuta yetkisi, savaş ilanı, olağanüstü hal ve sıkıyönetim ilanı gibi özel durumlarda yürütme olarak bakanlar kuruluyla ve yasama organı olarak meclisle birlikte çalışması zorunluluğu doğmaktadır. Bkz. Kemal Gözler, Devlet Başkanları: Bir Karşılaştırmalı Anayasa Hukuku İncelemesi, Bursa, Ekin Yayınları, 2016, s.190-198. 
Dış politikada, krize ilişkin kararlarda ikna edilmesi gereken grup ve/ya aktörlerin varlığı kısmen hükümetin koalisyon hükümeti olarak kurulup kurulmadığıyla ilintilidir. Ancak bu istisnai durumda yürütme erki koalisyon ortakları arasındaki dengeye göre pazarlıklar çerçevesinde işlemektedir. Koalisyonun oluşumuna göre karar biriminin “tek grup” veya “çoklu otonom aktör” olarak oluşması/işlemesi mümkündür. Çoklu otonom aktör şeklindeki karar biriminde farklı önceliklere sahip koalisyon ortaklarının kendi öncelikleriyle alınacak karar arasında uzlaşma yaratmaları ciddi çekişmelere, pazarlıklara yol açabilir ki bu durum özellikle krizlerde karar[laştırma] sürecini çıkmaza sürükleyebilir. ${ }^{16}$

Müdahil değişkenler bağlamında ele alındığında dış politikanın siyasal sorumluluğunu taşıyan hükümetin (Bakanlar Kurulu ve Başbakan) görev, yetki ve sorumlulukları Türkiye’nin iç hukuku bakımından 3 anayasal dönemde incelenebilir: 1924 Anayasası, 1961 Anayasası ve 1982 Anayasası. ${ }^{17}$ $\mathrm{Bu}$ anayasal dönemleri kesintiye uğratan askeri müdahale dönemlerindeyse yürütme (hatta yasama) erkinin askeri otorite tarafından üstlenilmiş olduğu görülür. Hatta bazı durumlarda yasama organı da geçici olarak görev yapamaz hale gelir.

Bazı farklılıklarla Türkiye'deki anayasalara göre yürütme erki kapsamında görev, yetki, sorumluluk Cumhurbaşkanlığı ve Bakanlar Kurulu’nun ilgi alanında şekillenmiştir. ${ }^{18} 1924$ Anayasası'nda yürütme Cumhurbaşkanı ve Bakanlar Kurulu'nun paylaştığı çift başlı bir yapıya sahiptir. Buna göre Cumhurbaşkanının siyasi sorumluluğu bulunmazken "1sdar edeceği bütün kararların Başbakan ve ilgili bakan tarafından imza edilmesi” gerekmiştir. Bu bağlamda dış politikanın saptanması ve dışa karşı temsiliyet ve kararların yürürlüğe konulması yürütme erkinin görev, yetki, sorumluluğunda bırakılmıştır. Bakanlar Kurulu ve Başbakan aynı zamanda devletin dışa karşı temsilini üstlenmiş ve TBMM’ye karşı sorumludur. 1961 ve 1982 Anayasalarında "her bakan, Başbakana karşı sorumlu olup ayrıca kendi yetkisi içindeki işlerden ve emri altındakilerin eylem ve işlemlerinden de sorumludur." Dolayısıyla Bakanlar Kurulu hükümetin genel siyasetinin yürütülmesinden müştereken sorumludur.

1982 Anayasasıyla Başbakan ve Bakanlar Kurulu'nun görev, yetki, sorumlulukları görece daha belirginleşmiş, Başbakanlık Teşkilatı’nın kurumsal yapısı gelişmiştir. Gerek kadro açısından gerekse üstlenmiş olduğu görevler açısından Başbakanlık Teşkilatı özellikle Bakanlar Kurulu’nun gündemine ve işleyişine katkıları açısından önemli bir işlevi üstlenmiştir. Benzer bir durum Dışişleri Bakanlığı için söylenebilir; 2010 tarihli 6004 Sayılı Dışişleri Bakanlığı Kanunu, Bakanlığın görev, yetki ve sorumluluğunun sınırlarını kurumsal düzlemde kurallara bağlamaktadır. Buna göre, “Türkiye Cumhuriyeti’nin dış politikasının tespiti için hazırlık çalışmaları yapmak ve tekliflerde bulunmak, Hükümet tarafından tayin ve tespit edilen hedef ve esaslara göre dış politikayı uygulamak

16 Bkz. Margaret G. Hermann, “How Decision Units Shape Foreign Policy: A Theoretical Framework”, International Studies Review, Cilt 3, No.2, 2001, s.47-81.

17 Süreç içerisinde 1982 Anayasasında 19 defada, toplam 184 değişiklik yapılmıştır. 16 Nisan 2017 tarihinde referanduma sunulan anayasa değişikliği ile yasama, yürütme erklerinin görev, yetki ve sorumlulukları önemli ölçüde değişikliğe uğramış ve yasama organının yürütmeyi denetleme olanağı büyük ölçüde kısıtlanırken yürütme içerisinde de Cumhurbaşkanı’nın yetkileri genişletilmiş ancak denetlenmesi için gerekli şartlar zorlaştırılmıştır. Bkz. http://www. anayasa.gov.tr/icsayfalar/mevzuat/1982anayasası.html, (Erişim Tarihi 4 Eylül 2018).

181924 Anayasası́na göre yürütme organının ikili bir yapı sergilediği söylenebilir; Cumhurbaşkanı ve İcra Vekilleri Heyeti [Bakanlar Kurulu]. 
ve koordine etmek" temel görevinin yanı sıra bir dizi görev üstlenmiş durumdadır. ${ }^{19}$ Kanunda Dışişleri Bakanlığı temsil görevinin yanında dış ilişkileri, müzakereleri yürütmek, yönlendirmek, geliştirmek, ülkenin çıkarlarını korumakla görevli ve yetkili kılınmıştır. Dışişleri Bakanlığı’nın hareket alanının sınırlarını ve esaslarını hükümet saptamaktadır. Dolayısıyla Dışişleri Bakanlığı hükümetin dış politika esasları ve kararlarının oluşum sürecine katkıda bulunan, dışarıda kararların uygulanmasını gözeterek etki ve yansımaları hakkında hükümeti bilgilendiren etkileşimli, çift yönlü bir işleve sahiptir. Aynı zamanda devletin ilk ağızdan resmi düzlemde dış ile muhatap olan yüzünü temsil eder.

Cumhuriyet dönemi dış politika karar sürecine bakıldığında kararların hangi uluslararası/ ulusal ortamda hangi karar birimi tarafından oluşturulduğu farklılık gösterir. Geniş bir zaman dilimine yayılarak oluşturulan dış politika kararlarına katkıda bulunan aktör sayısında görece artış görülebilir. $\mathrm{Bu}$ süreçte karardan etkilenmesi olası kurumların da görüş ve beklentileri kararlara yansıtılarak ortak yarar belirlenir. Bu gibi olağan durumlarda kararın aciliyetinin olmadığı düşünülebilir. Oysa kriz durumlarında karar birimi mevcut koşullarda en fazla yararı sağlayacağı düşünülen kararı kısıtlı zaman diliminde gerçekleştirir. Dolayısıyla kriz durumlarında zaman baskısı ve stresle mücadele edilirken sebep-sonuç-etki ilişkisi yeterince tartışılmamış seçenekler arasında doğru tercihi yapmak, başarı sağlamak karar biriminin temel uğraşısıdır. Bu bağlamda kriz durumlarındaki aciliyet ve zorunluluğa uygun olarak görece dar bir kadro kriz kararlarını oluşturur. Bununla birlikte, ister geniş isterse dar bir kadronun katkılarıyla oluşturulsun dış politika kararının siyasal sorumluluğunu üstlenecek aktör her durumda yürütme erkini elinde bulunduran siyasal liderdir.

Ancak kimi durumlarda siyasal liderle siyasal sorumlu karar birimi aynı kişi olmayabilir. Bu durumda siyasi liderle siyasal sorumlu karar birimi arasında uyumlu bir ilişkinin olup olmadığı önem kazanmaktadır. Eğer siyasal sorumluluğu olmayan liderin (örneğin cumhurbaşkanı) temel tercih ve öncelikleri doğrultusunda dış politika kararı oluşturulacaksa bunun siyasal sorumlu karar birimi (başbakan) tarafından kabul edilebilir olması gerekir. Cumhurbaşkanı ve başbakan arasındaki görevyetki-sorumluluk sınırlarının kesin hatlarla belirlenmemiş olduğu durumlarda taraflardan herhangi birinin diğerinin görev-yetki-sorumluluk alanına müdahale sayılabilecek girişimlerde bulunması karar[laştırma] açısından bir krizin tetikleyicisi olabilmektedir. ${ }^{20}$

19 Bkz. www.mfa.gov.tr/data/bakanlik/mevzuat-2013.pdf, (Erişim Tarihi 4 Eylül 2018).

202017 Anayasa değişikliğinin referandumla kabul edildiği dikkate alınırsa Cumhurbaşkanı́nın görev, yetki, sorumluluğunun yeniden belirlenmesi ve genişletilmesi söz konusudur. Buna göre nihai karar verici ve siyasi sorumlu olan karar birimi eskisinden farklı olarak Başbakan ve Bakanlar Kurulu değil Cumhurbaşkanı’dır. Bkz. Değişikliğe uğramış haliyle 1982 Anayasası 105. ve 106. md. http://www.anayasa.gov.tr/icsayfalar/mevzuat/1982anayasası.html, (Erişim Tarihi 4 Eylül 2018). 


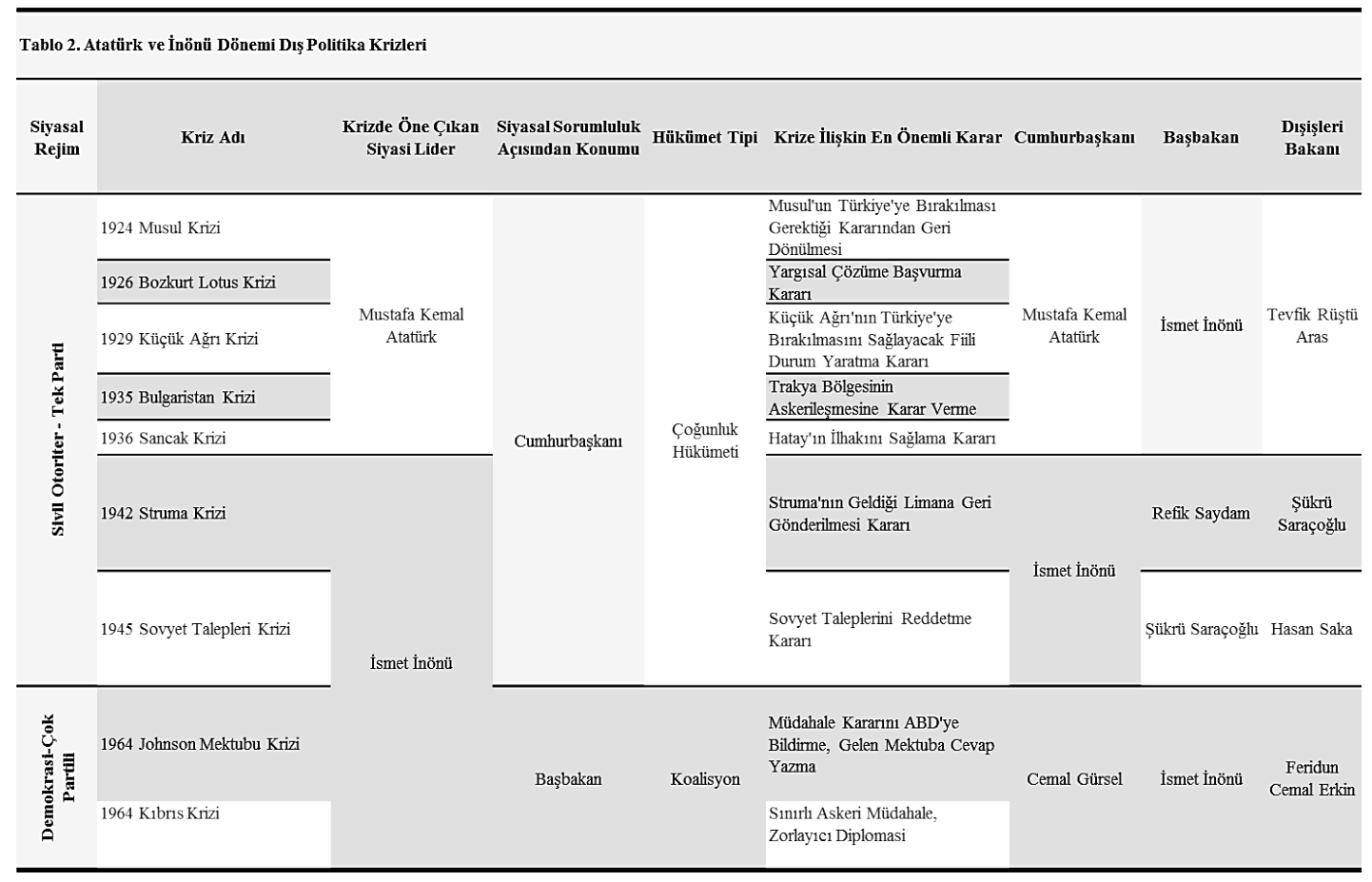

Gözler'e göre cumhurbaşkanlarının "devletin baş» olması sıfatıyla sahip oldukları görev ve yetkileri (temsil, gözetme, hakemlik, uyarma, görüş bildirme görev ve yetkileri, bilgilendirilme hakkı) bulunmakla beraber bu görevleri, yetkileri, hakları kullanırken tarafsızlık statülerine özellikle dikkat etmeleri gerekir. ${ }^{21}$ Gözler'in de belirttiği gibi:

Siyasal sorumluluğu olmayan devlet başkanının, siyasal sorumluluğu tamamıyla üstlenen bakanlar kurulunun yetkilerinin kullanılmasına katılması parlamenter sistemin mantığına aykırılık teşkil eder. O nedenle devlet başkanı, bakanlar kurulu toplantılarına başkanlık edebilse de... bu toplantılarda oy kullanamaz. Aksi takdirde, kolektif bir organ olan ve dolayısıyla oy birliği ile karar alan bakanlar kurulunun karar alma sürecini bloke etme yetkisini ele geçirmiş olur ki, sorumsuz bir makama bu yetkinin verilmesi parlamenter demokrasinin temel ilkeleriyle bağdaştırılamaz. ... Devlet başkanı ... önemli gördüğü bir konunun bakanlar kurulu tarafından görüşülmesini sağlayabilir... bakanlar kurulu toplantısında kendi görüşlerini de açıklayabilir. Uyarılarda bulunabilir. Ama bunlardan daha fazlasını yapamaz. ${ }^{22}$

Dış politika krizlerinde yürütme erki içerisindeki cumhurbaşkanı ve başbakanın krize ilişkin kararın oluşturulmasındaki katkısı her özgün krizin yönetim süreci incelendiğinde ortaya çıkmaktadır. Tablo 2'de görüldüğ̈ gibi 1923-1939 arası dönemde yaşanan dış politika krizlerinde siyasal sorumlu Başbakan İnönü olmasına karşın Cumhurbaşkanı Atatürk dış politikaya ilişkin kararlarda baskın aktördür. Bu dönemdeki beş dış politika krizinde devletin temel siyasasını Atatürk ve İnönü birlikte saptamışlardır.

Cumhurbaşkanı İnönü’nün kararlarda belirleyici olduğu iki dış politika krizi ise II. Dünya Savaşı sırasında ve sonrasında, tek parti otoriterliğinin henüz değişmediği dönemde yaşanmıştır. İnönü’nün başbakanlığı döneminde yaşanan iki krizdeyse dış politika kararlarının alınmasında İnönü’nün devlet deneyimi, liderlik vasıfları belirgindir. Cumhurbaşkanı Cemal Gürsel, İnönü’nün başbakanlığı sırasında

21 Gözler, Devlet Başkanları, s.118-121.

22 Ibid., s.179. 
ortaya çıkan bu krizlerde sürece müdahil değildir. Dolayısıyla, söz konusu liderlerin krizlerdeki rolleri incelenirken Cumhurbaşkanlıkları dönemindeki krizler de dikkate alınmalıdır.

Tablo 3'den görüleceği üzere İsmet İnönü, Süleyman Demirel, Ahmet Davutoğlu ve Binali Yıldırım başbakanlık dönemlerinde en fazla kriz yöneten karar birimidir. Ancak bu kısmen yanıltıcı/ eksiktir. Çünkü özellikle İnönü’nün başbakanlığında Atatürk’ün kararlardaki rolü/etkisi göz ardı edilemeyeceği gibi Demirel'in de Cumhurbaşkanı olduğu dönemlerde gerçekleşen dış politika krizlerindeki rolü, etkisi göz ardı edilemez. ${ }^{23}$ Davutoğlu dönemindeki krizlerde Cumhurbaşkanı Erdoğan'ın karar[laştırma] sürecinde baskın olduğu görülmektedir.

\begin{tabular}{|c|c|c|}
\hline Başbakanlar & Kriz Sayısı & Açıklama \\
\hline MUSTAFA KEMAL ATATÜRK & - & \\
\hline FEVZİ ÇAKMAK & - & \\
\hline HÜSEYİN RAUF ORBAY & - & \\
\hline ALİ FETHİ OKYAR & 1 & 1924Musul Krizi \\
\hline ISMET INOONTU & 7 & $\begin{array}{l}\text { 1924 Musul Krizi, 1926Bozkurt Lotus Krizi, 1929 Küçük Ağnı Krizi, } 1935 \text { Bulgaristan Krizi, } 1936 \text { Sancak Krizi, } 1964 \\
\text { Johnson Mektubu Krizi, } 1964 \text { Kıbrıs Krizi }\end{array}$ \\
\hline MAHMUT CELAL BAYAR & 2 & 1936 Sancak Krizi, 1935 Bulgaristan Krizi \\
\hline REFIK SAYDAM & 2 & 1936 Sancak Krizi, 1942 Struma Krizi \\
\hline AHMET FIKKRİ TÜZER & - & \\
\hline ŞƯKRƯ SARAÇOĞLU & 1 & 1945 Sovyet Talepleri Krizi \\
\hline MEHMET RECEPPEKER & 1 & 1945 Sovyet Talepleri Krizi \\
\hline HASAN SAKA & - & \\
\hline ŞEMSETTIN GÜNALTAY & - & \\
\hline ADNAN MENDERES & 3 & 6-7 Eylül 1955 Olaylan Krizi, 1957 Suriye Krizi, 1958 IRAK Krizi \\
\hline CEMAL GÜRSEL & - & \\
\hline EMIN FAHRETTIN ÖZDILEK & - & \\
\hline SUAD HAYRİ ÜRGÜPLÜ & - & \\
\hline SÜLEYMAN DEMIREL & 7 & $\begin{array}{l}\text { 1967 Kıbrıs Krizi, 1968-1974 Afyon Krizi, } 1974 \text { Kıbrıs Krizi, 1973-1976 Kıta Sahanlığı, 1974-1979 NOTAM-FIR, } 1991 \\
\text { Nahçıvan Krizi, } 1992 \text { TCG Muavenet Krizi }\end{array}$ \\
\hline NIHAT ERIM & 1 & 1968-1974 Afyon Krizi \\
\hline FERITT MELEN & 1 & 1968-1974 Afyon Krizi \\
\hline MEHMET NAIM TALU & 1 & 1968-1974 Afyon Krizi \\
\hline BÜLENT ECEVIT & 5 & $\begin{array}{l}\text { 1968-1974 Afyon Krizi, 1974 Kıbrıs Krizi, 1973-1976 Kıta Sahanlığı, 1974-1979 NOTAM-FIR, } 1998 \text { Suriye - Öcalan } \\
\text { Krizi }\end{array}$ \\
\hline SADİ IRMAK & 3 & 1974 Kıbris Krizi, 1973-1976 K1ta Sahanlı̆̆1, 1974-1979 NOTAM-FIR, \\
\hline BÜLEND ULUSU & 1 & 1981 Limni Krizi \\
\hline TURGUT ÖZAL & 5 & $\begin{array}{l}\text { 1981 Limni Krizi, 1984-1990 Batı Trakya Krizi, 1989 Bulgaristan Göçü Krizi, 1987 Kıta Sahanlığı Krizi, 1988-1991 } \\
\text { Iraklı Sığınmacılar Krizi }\end{array}$ \\
\hline ALİ BOZER & - & \\
\hline YILDIRIM AKBULUT & 3 & 1984-1990 Batı Trakya Krizi, 1989 Bulgaristan Göçü Krizi, 1988-1991 Iraklı Sığınmacılar Krizi \\
\hline MESUT YLMAZ & 2 & 1997 S300 Füze Krizi, 1998 Suriye-Öcalan Krizi \\
\hline ERDAL INÖNÜ & - & \\
\hline TANSU ÇILLER & 3 & 1991 Nahçıvan Krizi, 1994-1995 Ege Denizi Krizi, 1996 Kardak Krizi \\
\hline NECMETTIN ERBAKAN & 1 & 1997 S300 Füze Krizi \\
\hline ABDULLAH GÜL & - & \\
\hline R.T. ERDOĞAN & 5 & $\begin{array}{l}\text { 2003 Doğu Akdeniz MEB Krizi, } 2003 \text { Süleymaniye Çuval Krizi, } 2010 \text { Mavi Marmara Krizi, } 2011 \text { Suriye Krizi, } 2014 \\
\text { IşiD Rehine Krizi }\end{array}$ \\
\hline AHMET DAVUTOĞLU & 8 & $\begin{array}{l}\text { 2003 Doğu Akdeniz MEB Krizi, } 2003 \text { Süleymaniye Çuval Krizi, } 2010 \text { Mavi Marmara Krizi, } 2011 \text { Suriye Krizi, } 2014 \\
\text { IşiD Rehine Krizi, } 2015 \text { Süleyman Şah Türbesi Krizi,, } 2015 \text { SU-24 Rus Uçağmın Düşürülmesi Krizi, } 2015 \text { Başika Krizi }\end{array}$ \\
\hline BİNALİ YLDIRIM & 8 & $\begin{array}{l}\text { 2003 Doğu Akdeniz MEB Krizi, } 2003 \text { Süleymaniye Çuval Krizi, 2010 Mavi Marmara Krizi, } 2011 \text { Suriye Krizi, } 2015 \\
\text { Süleyman Şah Türbesi Krizi, 2015 SU-24 Rus Uçağının Düşürülmesi Krizi, 2015Başika Krizi, 2016 Frrat Kalkanı Krizi }\end{array}$ \\
\hline
\end{tabular}

23 Süleyman Demirel'in diş politika krizlerindeki etkisini operasyonel kod analizi çerçevesinde araştıran bir çalışma için bkz. Aydın Şıhmantepe, Türkiye'de Dı̧̧ Politika Krizlerinde Karar Alıcııın Operasyonel Kodları: Süleyman Demirel Örneği, Yayınlanmamış Doktora Tezi, İstanbul, Yıldız Teknik Üniversitesi Sosyal Bilimler Enstitüsü, 2016. 
Tablo 4'de Süleyman Demirel'in başbakan ve cumhurbaşkanı olduğu dönemlerdeki dış politika krizleri görülmektedir. 1974 Kıbrıs Krizi dâhil yedi dış politika krizinde Demirel başbakan olarak kriz sürecinde kararların sorumluluğunu üstlenen siyasi lider durumunda iken üç krizde cumhurbaşkanı olarak siyasi sorumluluğu olmamasına karşın kriz yönetim sürecinde rol üstlenerek krizin seyrini değiştirecek kararlara katkıda bulunmuştur. Başbakanlığı döneminde dış politika krizlerinde seçmenlerine ve siyasi bekasına ilişkin kaygı taşırken cumhurbaşkanlığı dönemindeki krizlerde devlet aklını temsil eden "bir bilen" rolündedir. ${ }^{24}$

\begin{tabular}{|c|c|c|c|c|c|c|c|c|}
\hline $\begin{array}{c}\text { Siyasal } \\
\text { Rejim }\end{array}$ & Kriz Adı & $\begin{array}{c}\text { Krizde Öne } \\
\text { Çıkan Siyasi } \\
\text { Lider }\end{array}$ & $\begin{array}{l}\text { Siyasal Sorumluluk } \\
\text { Açısından Konumu }\end{array}$ & Hükümet Tipi & $\begin{array}{c}\text { Krize İliş̧kin En Önemli } \\
\text { Karar }\end{array}$ & Cumhurbașkanı & Başbakan & $\begin{array}{c}\text { Dışşşleri } \\
\text { Bakanı }\end{array}$ \\
\hline \multirow{12}{*}{ 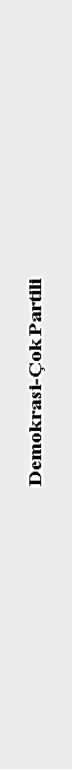 } & 1967 Kıbris Krizi & \multirow{12}{*}{$\begin{array}{l}\text { Süleyman } \\
\text { Demirel }\end{array}$} & \multirow{7}{*}{ Başbakan } & \multirow[t]{2}{*}{$\begin{array}{l}\text { Çoğunluk } \\
\text { Hükümeti }\end{array}$} & $\begin{array}{l}\text { Kuvvet Kullanma Tehdidi, } \\
\text { Vance Misyonunu } \\
\text { Destekleme Kararı }\end{array}$ & \multirow[t]{2}{*}{ Cevdet Sunay } & \multirow{7}{*}{$\begin{array}{l}\text { Süleyman } \\
\text { Demirel }\end{array}$} & \multirow{5}{*}{$\begin{array}{l}\text { İhsan Sabri } \\
\text { Çağlayangi }\end{array}$} \\
\hline & 1968-1974 Afyon Krizi & & & & $\begin{array}{l}\text { Haşhaş Ekimini } \\
\text { Yasaklamama Kararı }\end{array}$ & & & \\
\hline & 1973-1976Kıta Sahanlığı & & & & Casus Belli Kararı & \multirow{3}{*}{ Fahri Korutürk } & & \\
\hline & 1974 Kıbrıs Krizi & & & & & & & \\
\hline & 1974-1979NOTAM-FIR & & & & $\begin{array}{l}\text { Notamin Kaldirnimasi } \\
\text { Kararı }\end{array}$ & & & \\
\hline & 1992 Nahçıvan Krizi & & & & $\begin{array}{l}\text { Askeri Müdahale Yerine } \\
\text { Siyasi Destek ve Baskı } \\
\text { Kararı }\end{array}$ & \multirow[t]{2}{*}{ Turgut Özal } & & \multirow{2}{*}{$\begin{array}{l}\text { Hikmet } \\
\text { Çetin }\end{array}$} \\
\hline & 1992 TCG Muavenet Krizi & & & & Krizi Uyutma Kararı & & & \\
\hline & 1996 Kardak Krizi & & & Koalisyon & $\begin{array}{l}\text { İkinci Kayalığa Çıkma } \\
\text { Kararı }\end{array}$ & \multirow{5}{*}{ Süleyman Demirel } & $\begin{array}{l}\text { Tansu } \\
\text { Çiller }\end{array}$ & $\begin{array}{l}\text { Deniz } \\
\text { Baykal }\end{array}$ \\
\hline & \multirow[t]{2}{*}{1997 S300 Füze Krizi } & & & & $\begin{array}{l}\text { Füzelerin Adaya Gelmesi } \\
\text { Durumunda Vurulması } \\
\text { Kararı }\end{array}$ & & $\begin{array}{l}\text { Necmettin } \\
\text { Erbakan }\end{array}$ & $\begin{array}{l}\text { Tansu } \\
\text { Çiller }\end{array}$ \\
\hline & & & Cumhurbaşkanı & & & & $\begin{array}{l}\text { Mesut } \\
\text { Y1lmaz }\end{array}$ & \multirow{3}{*}{ İsmail Cem } \\
\hline & \multirow[t]{2}{*}{1998 Suriye - Öcalan Krizi } & & & & $\begin{array}{l}\text { Suriye Öcalan'a ve PKK'ya } \\
\text { Desteği Kesmezse } \\
\text { Müdahale Kararı }\end{array}$ & & $\begin{array}{l}\text { Mesut } \\
\text { Yllmaz }\end{array}$ & \\
\hline & & & & & & & $\begin{array}{l}\text { Bülent } \\
\text { Ecevit }\end{array}$ & \\
\hline
\end{tabular}

Turgut Özal, Tablo 5'de görüldüğü gibi, başbakanlığı dönemlerinde beş, cumhurbaşkanlığı dönemindeyse bir dış politika krizinde etkili olmuştur. Başbakanlığı döneminde Özal’ın pragmatik dış politika anlayışının krizlere yansıdığı görülür. Örneğin, 1987 kıta sahanlığı krizinde statükonun sürdürülmesini krizin çözümünde kritik seçenek olarak dillendiren Özal sürece müdahil olarak askeri seçeneklerin yarattığı tırmanmayı kontrol altına alabilmiştir. ${ }^{25}$

24 Bkz. Şı hmantepe, Türkiye'de Dış Politika Krizlerinde.

25 Bkz. Fuat Aksu, Türk Dış Politikasında Zorlayıcı Diplomasi, İstanbul, Bağlam Yayınları, 2008, s.188-189; Fuat Aksu, TürkYunan İlişkileri, Ankara, SAEMK Yay., 2001, s.80-83. 


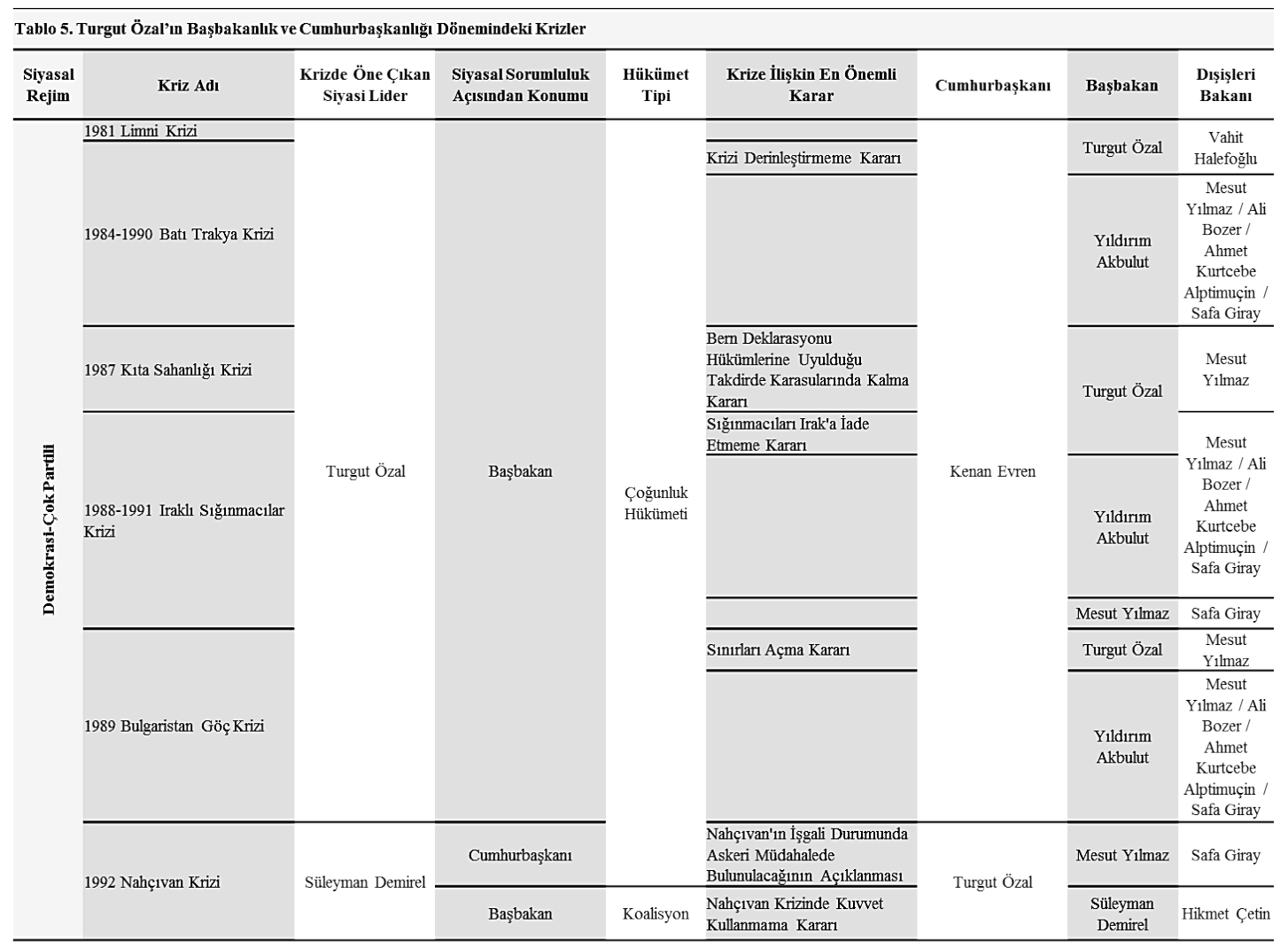

Özal, 1989 Bulgaristan göç krizini askeri seçeneklere başvurmadan zamana yayarak çözmüştür. Cumhurbaşkanlığı sürecindeyse farklı bir siyasa izlemiştir. Uluslararası sistemsel değişikliğe koşut olarak Özal'ın bölgesel güç boşluklarından yararlanmak istediği, Türkiye'nin ekonomik, siyasi, askeri açıdan avantajlarını çoğaltmaya çalıştığı görülür. Ancak bu çabalar geleneksel Türk dış politikası ilkeleriyle çeliştiği, siyasal sorumluluk açısından radikal bir değişikliği yansıttığı için eleştirilmiştir. Cumhurbaşkanı Özal, Irak’a askeri müdahale ve Nahçıvan krizleri sırasında ANAP hükümeti (Başbakan Yıldırım Akbulut) ile ters düştüğü kadar askeri seçkinlerle de (Genelkurmay Başkanı Org. Necip Torumtay) ters düşmüştür. ${ }^{26} 1992$ Nahçıvan Krizi'nin çeşitli safhalarında kuvvet kullanma tehdidini içeren stratejiler uygulanması gerektiğini dillendirmiştir. ${ }^{27}$ Ancak Başbakan Demirel bu konuda Cumhurbaşkanı Özal'dan farklı olarak krizin şiddete başvurmadan çözülmesi gerektiğini açıkça vurgulamıştır. ${ }^{28}$

\section{Dış Politika Krizlerinde Siyasal Sorumlular}

Krizlerde karar[laştırma] yapısının nasıl oluştuğu ve işlediğinin yanı sıra siyasal sorumluluğu üstenmiş olan aktör ve/ya aktörlerin bilişsel ve operasyonel kodları, kapasite ve yetenekleri krizlerin yönetim sürecini etkileyebilmektedir. Cumhuriyet döneminde 65 hükümet ve bu hükümetlere başkanlık etmiş 34 siyasi

26 Bkz. Mehmet Ali Birand ve Soner Yalçın, The Özal: Bir Davanın Öyküsü, İstanbul, Doğan Kitap, 2012, s.434-435, 439440; Hikmet Özdemir, Turgut Özal: Biyografi, İstanbul, Doğan Yay., 2014.

27 Sami Kohen, “Dişimizi Göstermek Gerekir”, Milliyet, 5 Nisan 1993, s.14.

28 Bkz. Fikret Bila, "İstiyorlarsa Gidip Savaşsınlar”, Milliyet, 20 Mayıs 1992, s.18. 
lider vardır. ${ }^{29}$ Bunlardan bir kısmı geçici hükümetlerin başında kısa süreli görev yaptıkları için krizlerde baskın bir rol üstlenmiş değildir. Dolayısıyla (Tablo 3) dış politika kriz süreçlerinde görev yapmış hükümet başkanlarının sayısını 22'dir. Yönetim süreçleri bakımından krizlerde siyasal sorumluluğu üstlenmiş olan hükümet başkanının Türk siyasal hayatının farklı dönemlerinde farklı krizleri yönetmiş olduğu görülür.

2017 yılı itibariyle sekiz krizle (bkz. Tablo 3) en fazla dış politika krizi yöneten hükümet başkanları Ahmet Davutoğlu ve Binali Yıldırım’dır. Bunları yedi krizle İsmet İnönü ve Süleyman Demirel, beşer krizle Bülent Ecevit ve Turgut Özal, Recep Tayyip Erdoğan izlemektedir. Davutoğlu, Erdoğan hükümetinde Dışişleri Bakanı olarak görev yaptığı dönemde tetiklenen krizleri başbakanlığı döneminde de yönetmiştir. Davutoğlu’ndan sonra başbakanlığa getirilen Binali Yıldırım, Davutoğlu döneminde tetiklenmiş, bir kısmı uyutulmuş krizlerin yönetimini üstlenmiştir. Yıldırım’ın başbakanlığı döneminden önce tetiklenen Mavi Marmara Krizi’nde taraflar arasında göreli bir yumuşama süreci geliştirilebilmiştir. Temmuz 2016 Fetullahçı Terör Örgütü-FETÖ kalkışmasının hemen ardından Rusya ile SU-24 uçağının düşürülmesiyle gerginleşen ilişkilerde yumuşama kaydedilerek krizin dozu düşürülebilmiştir. Bununla birlikte, Suriye konusundaki gelişmelere koşut olarak Türkiye'nin Suriye topraklarında başlattığı Fırat Kalkanı Operasyonu Suriye özelinde yeni bir kriz doğurmuştur. ${ }^{30}$

Benzer durum Süleyman Demirel için de söylenebilir; Demirel Türk siyasal hayatının farklı dönemlerinde hükümetler kurmuştur. Krizlerden bazıları bu hükümetlerden önce başlamış Demirel hükümetleri döneminde yönetilmiştir. Örneğin Tablo 4'de görüldüğü üzere 1967 Kıbrıs, 1968-1974 Haşhaş ekimi, 1992 Nahçıvan, 1992 Muavenet krizleri Demirel hükümetleri sırasında tetiklenmişlerdir. Ancak 1973-1976 kıta sahanlı̆̆ı, 1974 Kıbrıs, 1974-1979 NOTAM-FIR krizleri kendinden önceki hükümetler döneminde başlamış Demirel hükümetleri tarafından yönetilmişlerdir.

Diğer yandan, siyasal sorumluluk başbakanda olmasına rağmen krizlerde nihai karar birimi rolünü üstlenen baskın liderleri (cumhurbaşkanlarını) de görmekteyiz. 1939’a kadarki dönemde Cumhurbaşkanı Atatürk'ün önemli dış politika kararlarındaki rolü dönemin krizleri incelendiğinde açıkça görülmektedir. Benzer durum 1990 sonrasında da görülür. Cumhurbaşkanı Özal'ın 1991 Körfez Krizi'nde siyasal sorumlu hükümet olmasına rağmen doğrudan sürece müdahalelerde bulunması, Cumhurbaşkanı Demirel'in Kardak Kayalıkları Krizi’nde, Suriye-Öcalan krizinde süreci yönlendirmesi en belirgin örneklerdir. ${ }^{31}$

Cumhurbaşkanları kriz durumlarında dış politika kararlarında devletin ortak aklını temsil eden birleştirici aktör olarak siyasal sürece yön verebilmektedir. Ancak bu durum kriz yönetiminde hasmın karar sürecini zorlaştırabilmektedir. Eğer hükümet ile devlet başkanı arasında krize ilişkin değerlendirmeler farklıysa ve bu farklılık söylem, eylem olarak davranışlara, tercihlere yansıyorsa bu durumda kriz yönetim sürecinde aksaklıklar doğabilmektedir. Muhatap açısından Türkiye'nin

29 Cumhuriyet döneminde başlıca beş siyasi lider hem başbakan hem de cumhurbaşkanı olarak görev yapmıştır. İsmet İnönü, Turgut Özal, Süleyman Demirel, Abdullah Gül ve Recep Tayyip Erdoğan başbakanlıklarının ardından cumhurbaşkanı olarak da görev yapmışlardır. Bunlardan sadece İsmet İnönü cumhurbaşkanlığı görevinden sonra siyasal hayata geri dönmüş ve süreç içinde başbakan olarak görev üstlenmiştir. Abdullah Gül'ün başbakanlığı ise 58. hükümet dönemi ile sınırlı olmuş ve yaklaşık 4 ay sürmüştür.

30 Binali Yıldırım’ın başbakanlığı ile beraber izlenen dış politikanın görünür olumsuz sonuçlarını törpülemeye dönük bir diplomasi-diyalog sürecinin işletilmeye çalışıldığı söylenebilir. Türkiye'nin bölgesel muhataplarıyla Davutoğlu döneminde bozulan ilişkiler düzeltilmeye çalışılırken Rusya, Türkiye'nin ABD ile ilişkilerinde ve bölgeye bakışında dengeleyici aktör pozisyonuna gelmiştir.

31 Özal'dan farklı olarak Cumhurbaşkanı Demirel'in Kardak krizi ve Öcalan/Suriye Krizi’nde Gözler'in ifade etmiş olduğu "uyarma ve görüş bildirme" sınırları içerisinde kaldığı söylenebilir. 
krize ilişkin resmi görüşünü yürütmenin içerisindeki hangi aktörün dillendirmiş olduğu kargaşa yaratabilmektedir. ${ }^{32}$ Oysa kriz yönetimi açısından kriz sürecinde çok seslilikten kaçınmak temel önceliklerden biridir. ${ }^{33}$

Siyasal sorumlu olmamasına rağmen karar sürecindeki askeri yetkililerin kamuoyu önünde görüşlerini dillendirmesi çok başlılığı pekiştirdiği gibi krizlerin sağlıklı yürütülmesini zorlaştırabilmektedir. ${ }^{34}$ Ancak başarılı bir kriz yönetimi diplomasi-savaş sarkacında askeri kuvvet kullanma yeteneklerinin başarılı, inandırıcı kullanımını gerektirir. Dolayısıyla kuvvet kullanma tehdidinden yararlanılması gerektiğinde siyasi karar birimlerinin askeri bürokrasinin sunmuş olduğu araç ve yöntemlerden yararlanarak en uygun tercihi uyguladıkları görülür. ${ }^{35}$ Türkiye'nin dış politika krizlerinde bu anlamda 2000’li yıllara değin tutarlı bir ilişki ve denge vardır. Kuvvet kullanma ve/ ya savaş kararı gerektiren krizlerde askeri bürokrasi kapasite ve yetenekleri doğrultusunda sivil siyasi sorumluların çizdiği sınırlarda başarılı kriz yönetim seçenekleri sunmuşlardır.

Ancak 2000'lerdeki dış politika krizlerinde askeri bürokrasi karar sürecindeki etkisini görece yitirmiştir. 2003 sonrasında demokratikleşme-sivilleşme amaçlı anayasal-yasal değişiklik Türkiye’de asker-sivil ilişkilerinde askerin görünürlügünü azaltmıştır. Bu durum askeri bürokrasinin karar sürecine yapmış olduğu özgün teknik katkıyı üstlenecek sivil bürokratik mekanizmalar oluşturulmadığı için karmaşık sorunlar yaratabilmiştir. Kaldı ki askeri bürokrasinin görev alanına giren konularda karar birimlerinin ihtiyaç duyacağı bilgilere sivil bürokrasinin tamamıyla hâkim olması beklenemeyeceği gibi askeri bürokrasi aynı zamanda icracı statüdedir. Dolayısıyla alınacak kararların askeri olasılıkları dikkate almayı gerektirdiği, askeri araç ve yöntemlerin kullanılmasına ihtiyaç duyulduğu durumlarda askeri bürokrasinin karar yapı ve sürecinde yer almaması rasyonel de değildir. Ayrıca Türkiye’nin iç siyasetinde TSK'nın etkisinin azalması iç-dış itibarını/direncini zayıflatan çok sayıda davalarla da ilintilidir. ${ }^{36}$

Genellikle çatışmanın krize evrilme uyaranlarını sergilediği aşamalardan itibaren karar yapısı içerisindeki aktörler siyasal sorumlu aktörün direktifleri doğrultusunda siyasa oluşturur. Kriz sürecindeki değerlendirmelerinde dışişleri bakanlığı, genelkurmay başkanlığı bürokrasisi mevcut riskleri/seçenekleri sıralayarak siyasal karar biriminin tercihini kolaylaştırır. Uygulanacak dış politika beklenen yararı sağlamadığında siyasi sorumluluk karar birimine aittir. Karar yapısında yer alan bürokrat/teknokratlar

32 Örneğin 1992 Nahcivan Krizi sırasında Cumhurbaşkanı Özal’ın askeri kuvvet kullanımına yönelik ifadeleri Başbakan Demirel tarafından tepki ile karşılanmıştır. 23 Mayıs 1992 tarihli konuşmasında Başbakan Demirel “... savaşacak tek devlet biz miyiz? Askeri olan tek devlet biz miyiz? Bu duruma rağmen hâlâ niye harp etmiyorsunuz derlerse ben de o zaman kim harp etmek istiyorsa buyursun gitsin derim." diyerek bu tepkisini açıça ortaya koymuştur. Bkz. Fikret Bila, "ABD İstediğimizi Yaptı", Milliyet, 23 Mayıs 1992, s.7.

33 Bkz. Alexander L. George, "A Provisional Theory of Crisis Management”, Alexander L. George (der.), Avoiding War: Problems of Crisis Management, Boulder, Westview Press, 1991, s.22-27.

34 Kriz yönetim sürecinde askeri hareketlilik, sembol ve eylemlerin aşırı görünürlügü hasmın üzerinde baskı yaratsa da diplomatik-siyasi manevra alanını kısıtlayabilir. Diplomasiyle askeri seçenekler arasında hassas bir denge kurulması gerekir. İletişim kanallarının açı tutulması, askeri hareketlilik düzeyinde denge, bazen duraklamalar yaratarak hasmın durumu algılayıp algılamadığının gözlenmesi etkili kriz yönetimi için gereklidir.

35 Milli Güvenlik Kurulu'nun dış politika kararlarındaki rolüne ilişkin olarak bkz. Bulut Gürpınar, "Milli Güvenlik Kurulu ve Dış Politika”, Uluslararası İlişkiler, Cilt 10, Sayı 39, 2013, s.73-104.

$36 \mathrm{Bu}$ davalardan bazıları şunlardır; Ergenekon, Balyoz, İstanbul Askeri Casusluk, İzmir Askeri Casusluk, Atabeyler, Malatya Zirve, 28 Şubat, ÇYDD, İnternet Andıcı, Poyrazköy, Kafes, Amirallere Suikast, Erzincan Ergenekon, Hakkâri-Şemdinli, Odatv. Davalar hakkında bkz.http://www.kumpasder.org.tr/davalar/, (Erişim Tarihi 10 Ağustos 2018). Davaların gerekçeli mahkeme kararlarında sanıklara isnat edilen suçlara ilişkin delillerin "sahte" olarak oluşturulduğu kanaatine varılmıştır. Bir örnek olarak Balyoz Davası Gerekçeli Kararına bakılabilir, https://cdogangercekler.files.wordpress.com/2015/05/balyozdavasc4b1-gerekceli-karar_2014-188.pdf, (Erişim Tarihi 10 Ağustos 2018). Ayrıca bkz. Yaprak Gürsoy, "Türkiye'de SivilAsker İlişkilerinin Dönüşümünün Sebepleri”, Uluslararası İlişkiler, Cilt 11, Sayı 43, 2014, s.157-180. 
kararlarda ancak sınılı bir idari sorumluluğu vardır. Oysa bakanların bakanlar kurulu içerisinde yer almalarından dolayı kararlarda ortaklaşa siyasal sorumlulukları vardır. ${ }^{37}$ Diğer yandan, karar yapısında yer alan diğer aktörlerin görüş ve değerlendirmelerini dikkate almayan nihai karar biriminin etkili karar alması da zordur. Oysa alternatif değerlendirmelere, tartışmalara açık bir karar yapısı-süreci oluşturulduğu takdirde nihai karar birimi var olan seçeneklerin olumlu-olumsuz etkilerini dikkate alarak en "doğru" siyasayı uygulamak için gerekli direktifleri verir, siyasi sorumluluğu üstlenir. ${ }^{38}$

Başbakan ve cumhurbaşkanının birlikte yürütme erkini oluşturması bu iki makamın uyumlu bir işleyişte uzlaşmalarını gerektirir. Özellikle kamu bürokrasisi açısından birbiriyle çelişen direktiflerle karşılaşmaları durumunda başbakanın ve/ya cumhurbaşkanının direktiflerinden hangisine uymaları gerekeceği siyasi bir krizi doğurur. ${ }^{39} \mathrm{Bu}$ durumda aktörlerden birisi anayasal görev, yetki sınırlarına geri dönmediği takdirde kurumlar arası çatışma, durumu istikrarsızlaştırmaktadır. ${ }^{40}$

Örneğin İsmet İnönü’nün Cumhuriyetin ilk yıllarında uzun süreli başbakanlık yapmış olması Cumhuriyetin kurucu kadrosu içerisinde yer alması ve Atatürk ile büyük ölçüde uyumlu çalışabilmesi bu dönemdeki önemli kararlarda ortak karar[laştırma] sürecinin işletilebildiğini göstermektedir. Devlet merkezli tercih ve öncelikler çerçevesinde siyasal karar biriminin uzlaştırıcı kimliği kriz süreçlerinde dışa karşı dayanışmayı temsil etmesi bakımından önemlidir. 1960 sonrasında İnönü’nün Türkiye'deki siyasi istikrarsızlıklar sırasında başbakanlığı üstlenmesi Kıbrıs sorununun yükselişine denk geldiği için ayrıca dikkate değerdir. "Ulusal dava” nın savunulmasıyla askeri seçenekler arasında tercih yapmak gerektiğinde Başbakan İnönü devletin saygınlığı ve bekasıyla koşut rasyonel tercihlere odaklanmıştır. Bu durum İnönü’nün iç siyasette eleştirilmesine karşın serüvenci bir dış politika izlenmesi halinde yaşanacak olumsuzlukları önlemeye yaramıştır.

Süleyman Demirel'in başbakanlığının İnönü döneminde başlayan krizlerin tekrarlarıyla şekillendiği söylenebilir. İnönünün hükümet dönemindeki dış politika krizlerinin tamamı hükümet dönemlerinin ürünüdür. Yedi krizden beşi 1945 öncesi, iki kriz ise 1945 sonrası dönemde yaşanmıştır. Davutoğlu ise sekiz dış politika krizi yönetmekle birlikte krizlerin beşi kendinden önceki Erdoğan hükümetleri sırasında tetiklenmiştir. ${ }^{41}$ Bülent Ecevit ve Turgut Özal da beşer kriz yönetmiştir. Ecevit'in

37 Son yıllardaki dış politika krizlerinde karar yapısında bulunan çeşitli düzeydeki aktörlerin uyarılarına rağmen siyasal karar biriminin riskli kararların alınmasında ve uygulanmasında ısrarlı oldukları görülmektedir. Örneğin 22 Haziran 2012 tarihinde RF-4 uçağının düşmesinden sonra Türkiye'nin Suriye sınırındaki uçuşlarda angajman kurallarını değiştirmesinin ardından Hava Kuvvetleri Komutanlığı/Genelkurmay angajman kurallarının düşmanca tavır takınan uçaklara karşı uygulanmasının gerekliliği konusunda yaptığı uyarılar siyasi kanat tarafından dikkate alınmamış ve angajman kuralları ayrım gözetilmeksizin her türden uçağa karşı uygulanmıştır. Bunun sonucunda ise SU-24 Rus uçağı doğrudan Türkiye'ye karşı düşmanca bir tavır içerisinde değilken düşürülmüştür. Bkz. Deniz Zeyrek, “Rus Uçağıyla İlgili 29 Ekim Sırrı”, Hürriyet, 13 Ocak 2017, http:// www.hurriyet.com.tr/yazarlar/deniz-zeyrek/rus-ucagiyla-ilgili-29-ekim-sirri-40334828, (Erişim Tarihi 4 Eylül 2018).

38 Örneğin 1991 Irak Krizi sırasında oluşturulan kriz komitesinde yer alan Dışişleri Bakanı Ali Bozer Türkiye'nin askeri harekâta katılma konusundaki çekincelerini dillendirerek Cumhurbaşkanı Özal'la ters düşmüştür. Buna rağmen Bozer'in devlet adına alınacak kararları uygulamaktan kaçınmayacağını ifade ettiği görülür: “... Burada bir kriz komitesi var. Siz kararı verin. Ben dışişleri bakanı olarak gerekeni yaparım. Kararı verdiler, ben de taktiğimi yaptım.” Birand ve Yalçın, The Özal, s.433.

39 Örneğin Körfez Krizi sırasında Genelkurmay Başkanı́nın Cumhurbaşkanı Özal ve Başbakan Akbulut ile ilişkilerinde benzer sıkıntılar yaşanmıştır. Bkz. Özdemir, Turgut Özal, s.383-408.

401991 Körfez Krizi sırasında Cumhurbaşkanı Özal'ın Irak’a askeri müdahale yapılmasını teşvik etmesine karşın Başbakan Akbulut'un buna direnerek tüm siyasal sorumluluğu üstlenmesi çarpıcı bir örnektir. Bkz. Birand ve Yalçın, The Özal, s.435, 439-440.

41 Davutoğlu, başbakanlığından önce Erdoğan hükümetlerinde Dışişleri Bakanıdır. Dışişleri Bakanlığı’ndan önce ise Erdoğan’ın danışmanları arasında yer almıştır. Adalet ve Kalkınma Partisi (AK Parti/AKP) hükümetlerinin dış politikasının belirlenmesinde olduğu kadar söz konusu krizlerde de karar yapısında yer aldığı söylenebilir. Danışmanlığı dönemi bir yana bırakılsa bile AK Parti/AKP hükümetlerinde Bakanlar Kurulu içerisinde yer almış olması siyasal sorumluluk açısından Davutoğlu'nu da dikkate almayı gerektirmektedir. 
yönettiği krizlerden sadece haşhaş ekimi krizi kendinden önceki hükümetler sırasında tetiklenmiştir. ${ }^{42}$ Diğer krizler ise kendi hükümet döneminde ortaya çıkmıştır. Aynı durum Özal için de söylenebilir. 1981 Limni Krizi, 1983 öncesinde yaşanmıştır. Bununla birlikte üç krizde komşu ülkelerle insani nitelikli kriz yaşanmıştır. Batı Trakya ve Bulgaristan krizlerinde azınlıkların/soydaşların hak ve statülerine yönelik saldırılar yaşanmaktadır ve Türkiye, antlaşmalarla bu azınlıkların statülerini korumakla yükümlüdür. Iraklı Kürt sığınmacılara ilişkin krizdeyse Türkiye yoğun sığınmacı akını dolayısıyla Irak ile kriz yaşamıştır.

Kesintisiz en uzun başbakanlık görevini sürdürmüş olan Erdoğan'ın hükümetleri döneminde tetiklenen dış politika krizleri Davutoğlu döneminde de sürmüştür. Davutoğlu döneminde çözülen tek kriz ise IŞiDD Rehineler Krizi olmuştur. ${ }^{43}$ Doğu Akdeniz Münhasır Ekonomik Bölge (MEB) Krizi dışındaki krizlerde karar biriminin krize ilişkin siyasası savunmacı veya saldırgan kriz yönetim stratejileri bakımından tartışmalıdır. ${ }^{44}$ Gelişen ve tasarlanmış kriz özellikleriyle söz konusu krizlerde karar biriminin kriz anlamını yüklemesi için gerekli olan temel hedef ve değerlerin neler olduğu, hangi risk, tehlike, tehdit veya saldırıyla karşılaşıldığına dair inandırıcılığı yüksek gerekçe bulmak zordur.

\begin{tabular}{|c|c|c|c|c|c|c|c|c|}
\hline $\begin{array}{l}\text { Siyasal } \\
\text { Rejim }\end{array}$ & Kriz Adı & $\begin{array}{c}\text { Krizde Öne } \\
\text { Çıkan Siyasi } \\
\text { Lider }\end{array}$ & $\begin{array}{l}\text { Siyasal } \\
\text { Sorumluluk } \\
\text { Açısından } \\
\text { Konumu }\end{array}$ & $\begin{array}{c}\text { Hükümet } \\
\text { Tipi }\end{array}$ & Krize İlişkin En Önemli Karar & Cumhurbaşkanı & Başbakan & $\begin{array}{l}\text { Dışişleri } \\
\text { Bakanı }\end{array}$ \\
\hline \multirow{8}{*}{ 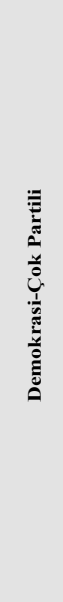 } & $\begin{array}{l}2003 \text { Doğu Akdeniz } \\
\text { MEB Krizi }\end{array}$ & \multirow{8}{*}{$\begin{array}{l}\text { Recep Tayyip } \\
\text { Erdoğan }\end{array}$} & \multirow{5}{*}{ Başbakan } & \multirow{8}{*}{$\begin{array}{l}\text { Çoğunluk } \\
\text { Hükümeti }\end{array}$} & Kısasa Kısas Kararı & \multirow{2}{*}{ Ahmet Necdet Sezer } & \multirow{5}{*}{$\begin{array}{l}\text { Recep } \\
\text { Tayyip } \\
\text { Erdoğan }\end{array}$} & \multirow{2}{*}{ Abdullah Gül } \\
\hline & $\begin{array}{l}2003 \text { Süleymaniye } \\
\text { Çuval Krizi }\end{array}$ & & & & Krizi Uyutma Kararı & & & \\
\hline & $\begin{array}{l}\text { 2010 Mavi Marmara } \\
\text { Krizi }\end{array}$ & & & & İsrail'e Baskı ve Yaptırım Kararı & & & \\
\hline & 2011 Suriye Krizi & & & & $\begin{array}{l}\text { Suriye'de Rejim Değişikliği İçin } \\
\text { Muhalifleri Destekleme Kararı }\end{array}$ & Abdullah Gül & & $\begin{array}{l}\text { Ahmet } \\
\text { Davutoğlu }\end{array}$ \\
\hline & 2014 IŞiD Rehine Krizi & & & & $\begin{array}{l}\text { IŞiD'in Konsolosluğa Müdahalesini } \\
\text { Öngörememe ve Pazarlığı Tercih } \\
\text { Etme }\end{array}$ & & & \\
\hline & $\begin{array}{l}2015 \text { Süleyman Şah } \\
\text { Türbesi Krizi }\end{array}$ & & \multirow{3}{*}{ Cumhurbaşkanı } & & $\begin{array}{l}\text { Askeri Operasyonla Türbenin Terk } \\
\text { Edilerek Sınıra Yakın Bölgeye } \\
\text { Taşınması Kararı }\end{array}$ & \multirow{3}{*}{$\begin{array}{l}\text { Recep Tayyip } \\
\text { Erdoğan }\end{array}$} & \multirow{2}{*}{$\begin{array}{l}\text { Ahmet } \\
\text { Davutoğlu }\end{array}$} & $\begin{array}{l}\text { Mevlüt } \\
\text { Çavuşoğlu }\end{array}$ \\
\hline & $\begin{array}{l}2015 \text { SU-24 Rus } \\
\text { Uçağının Düşürülmesi } \\
\text { Krizi }\end{array}$ & & & & $\begin{array}{l}\text { Angajman Kurallarına Karar } \\
\text { Vermek }\end{array}$ & & & $\begin{array}{l}\text { Feridun } \\
\text { Sinirlioğlu }\end{array}$ \\
\hline & 2015 Başika Krizi & & & & $\begin{array}{l}\text { Başika'da Türk Askerinn } \\
\text { Konuşlandırılması ve Geri } \\
\text { Çekilmemesi Kararı }\end{array}$ & & $\begin{array}{l}\text { Ahmet } \\
\text { Davutoğlu/ } \\
\text { Binali } \\
\text { Yeldırım }\end{array}$ & $\begin{array}{l}\text { Feridun } \\
\text { Sinirlioğlu / } \\
\text { Mevlüt } \\
\text { Cavușoğlu }\end{array}$ \\
\hline
\end{tabular}

Diğer yandan, gerek başbakanlığı gerekse cumhurbaşkanlığı döneminde siyasal kararlardaki etkisi dikkate alındığında Erdoğan’’n krizlerdeki dış politika kararlarında temel siyasayı belirlediği

42 Bkz. Nuray Okumuş, Türk-Amerikan İlişkilerinde Haşhaş Ekimi Krizi (1968-1975): Kriz Yönetimi Açısından Bir İnceleme, Yayınlanmamış Yüksek Lisans Tezi, Yıldız Teknik Üniversitesi Sosyal Bilimler Enstitüsü, 2018.

43 Musul Başkonsolosluğu’nun IŞİD militanları tarafından basılarak personelin rehin alınması süreci incelendiğinde bu krizin önlenebileceği görülür. IŞİD’in Musul’a yönelmesiyle ortaya çıkan riskler Türkiye'deki siyasal karar birimi/yapısı/ süreci tarafından yeterince önemsenmemiş, deyim yerindeyse krize davetiye çıartılmıştır. Rehine krizi ise yürütülen tartışmalı pazarlıklar sonucunda çözülebilmiştir. IŞİD hakkında bkz. Haldun Yalçınkaya, "IŞİं'in Yabancı Savaşçıları ve Yarattı̆̆ı Tehdit: Türkiye’nin Tecrübesi (2014-2016)”, Uluslararası İlişkiler Dergisi, Cilt 14, Sayı 53, 2017, s. 23-44.

44 Bkz. Tuğçe Kafdağlı, Kriz Yönetimi Açısından Doğu Akdeniz Deniz Yetki Alanları Uyuşmazliğı, Yayınlanmamış Yüksek Lisans Tezi, İstanbul, Yıldız Teknik Üniversitesi Sosyal Bilimler Enstitüsü, 2013. 
söylenebilir. ${ }^{45}$ Kriz yönetimi açısından bu krizler geçmiş dönemlerdeki krizlerden yönetimsel özellikler bakımından farklılaşmıştır. 2003-2016 arasında ortaya çıkan 5 (+3) kriz analiz edildiğinde bu krizler teknik açıdan siyasi karar yapı ve biriminin (en azından uyuşmazlık-çatışma sürecinde) öngörebileceği krizlerdir. Diğer bir ifadeyle, izlenen dış politikanın olası etki ve sonuçları açısından bakıldığında bu uyuşmazlıkların kriz doğurma riski öngörülebilirdir.

\section{Hükümet Şekli ve Dış Politika Krizlerinin Dağılımı}

Yönetim biçiminin demokratikliği, hükümetteki partinin serbest seçimlerle iktidara gelip gelmediği, çoğunluk, koalisyon veya azınlık hükümeti olup olmadığının yanı sıra Türkiye örneğinde askeri müdahalelerle demokratik yönetimin kesintiye uğramış olması karar yapısının işleyişi bakımından farklı analizler yapmaya olanak tanımaktadır. 1946 yılında Türkiye'de çok partili siyasal yaşama geçilmiş olmasına rağmen 1950 seçimleriyle iktidar değişmiş, 1960 yılına değin Demokrat Parti hükümetleri yönetimde kalmıştır. 1923-1960 arasında hükümetler çoğunluk hükümetleridir. CHP hükümetleri döneminde yedi, DP hükümetleri döneminde üç dış politika krizi yönetilmiştir. Özellikle Sovyet taleplerine ilişkin krizin 1947 sonrasında durağanlaşması ve Sovyet toprak taleplerinin dillendirilmemesi bir yumuşama işareti olarak görülmesine rağmen kriz sonrası evre görece daha uzun döneme yayılmış ve CHP iktidarı döneminde başlayan krizin izleri DP hükümetleri döneminde de sürmüştür.

20 Mayıs 1960- 27 Ekim 1961 tarihleri arasında 27 Mayıs askeri müdahalesinin bir sonucu olarak Cemal Gürsel'in başbakanlığında 24. ve 25. partiler-üstü hükümetler görev yapmıştır. Bu dönemde dış politika krizi yaşanmamıştır. Çok partili dönemin ilk koalisyonu ise CHP'nin AP ile gerçekleştirmiş olduğu, bakanlar kurulunda bağımsız milletvekillerine de yer verilen 26 . hükümettir. ${ }^{46}$ 25 Aralık 1963'le 20 Şubat 1965 arasında hükümette bulunan ikinci koalisyon döneminde iki önemli dış politika krizi yaşanmıştır; 1964 Johnson Mektubu Krizi ve 1964 Kıbrıs Krizi.

Cumhuriyet döneminde 2016 yılına değin 30 çoğunluk hükümeti toplam 36 krizden 24'ünü yönetmiştir. Tablo 7'de çoğunluk hükümetlerinin yönettiği krizler görülmektedir. Koalisyon hükümetlerinin sayısı geçici koalisyonlar (2) dahil olmak üzere toplamda 14'tür. Tablo 8'de görüleceği gibi, bunlardan 12 koalisyon hükümeti döneminde 12 dış politika krizi yönetilmiştir.

Krizlere ilişkin dış politika kararları siyasal sorumlu başbakan ve bakanlar kurulunun ortak iradesini ve tercihini yansıtır. Bu genel anlamda doğru olsa da özellikle kriz yönetim sürecinde siyasal sorumluluğu bulunmamakla birlikte cumhurbaşkanının başbakan ve dışişleri bakanından daha baskın bir rol üstlendiğine rastlanmaktadır. Tek partili dönemde bu durum özellikle kurucu liderler açısından daha belirgindir. Cumhurbaşkanı Atatürk'ün siyasal yaşamdaki etki ve rolü, devletin önemli konularında Başbakan ve Bakanlar Kurulu’ yla kurduğu iletişim krizlerde belirleyici olmuştur. Musul, Küçük Ağrı, Bulgaristan, Hatay krizlerinde Cumhurbaşkanı Atatürk’ün karizmatik liderlik özellikleri sürecin işleyişini etkilemiştir.

Anavatan Partisi'nin (ANAP) kurmuş olduğu çoğunluk hükümetleri uluslararası sistemde ikinci dalga Soğuk Savaş dönemiyle bu dönemin sonlandığı 1991 yılına değin sürmüştür. Bu dönemde

45 Bkz. Ömer Ak, “Liderlik Profili Analizi ve Dış Politika: Turgut Özal ve Recep Tayyip Erdoğan”, Ertan Efegil ve Rıdvan Kalaycı (der.), Dış Politika Teorileri Bağlamında Türk Dış Politikasının Analizi, Cilt 1, Ankara, Nobel Yayınevi, 2012, s.501-527.

46 Söz konusu CHP-AP Hükümeti 20 Kasım 1961-25 Haziran 1962 tarihleri arasında görev yapmıştır. AP’nin hükümetten çekilmesinden sonra 27. Hükümet CHP, YTP, CKMP ve Bağımsız Milletvekilleri ile kurulmuş 25 Haziran 1962-25 Aralık 1963 tarihleri arasında görev yapmıştır. 
ANAP hükümetleri altı konuda dış politika krizi yaşamıştır. Yunanistan, Bulgaristan, Irak ve Ermenistan ile yaşadığı krizlerin bazılarında ise Türkiye ahdi yükümlülükleri dolayısıyla zaman zaman kuvvet kullanma tehdidinden yararlanarak krizi sonlandırmıştır. Karar sürecinin işleyişi bakımından Özal'ın pragmatik dış politika davranışları krizlere yansımıştır. ${ }^{47}$ Örneğin 1987 Ege Denizi Kıta Sahanlığı Krizi sırasında Özal'ın ABD'de geçirdiği kalp ameliyatından sonra ülkeye dönerken kriz yönetimine müdahalesi Özal'ın süreçteki izlerini yansıtmaktadır. ${ }^{48}$ Özal, Londra'da sürece müdahil olmuş, İngiliz televizyonlarının canlı yayınında krizi çözecek açıklamayı yapmıştır. Özal'ın Türkiye’ye dönüşüyle iki ülke arasında Davos Ruhu olarak adlandırılan diyalog sürecinin zemini atılabilmiştir. Genel olarak bu dönemde Özal'ın Türkiye ve Yunanistan ile bu ülkelerdeki Türk/Müslüman azınlığın haklarının ihlalinden kaynaklanan krizlerde görece daha ılımlı bir dil kullanmış olması dikkat çekmektedir. Bu bağlamda, özellikle Bulgaristan'daki 1989 göç krizinde doğrudan Bulgaristan’la ilişkileri sonlandıracak bir dış politika izlemek yerine bu ülke üzerinde baskı oluşturacak ve krizi zamana yayacak stratejiler izlemiştir. Ancak kitlesel göç dolayısıyla hükümet yoğun eleştirilerin hedefi haline gelmiştir.

\begin{tabular}{|c|c|c|c|c|c|c|c|c|c|c|}
\hline HÜKÜMET SAYISI & BaşBakAn & PARTisi & \multicolumn{8}{|c|}{ DIȘ POLiTiKA KRIZLERI } \\
\hline 1. НÜKÜMET & \multirow{2}{*}{ ISMET INÖNÜ } & \multirow{2}{*}{$\begin{array}{l}\text { HALK } \\
\text { FIRKASI }\end{array}$} & \multirow{4}{*}{\multicolumn{2}{|c|}{1924 MUSUL KRizi }} & & & & & & \\
\hline 2. НÜКÜMET & & & & & & & & & & \\
\hline 3. НÜКÜMET & ALI FETHI OKYAR & CHF & & & & & & & & \\
\hline 4. НÜKÜMET & \multirow{3}{*}{ ISMET INÖNÜ } & \multirow{3}{*}{$\mathrm{CHF}$} & & & \multicolumn{6}{|c|}{1926 BOZKURT LOTUS KRIZi } \\
\hline 5. HÜKÜMET & & & \multicolumn{8}{|c|}{1929 KÜÇÜK AĞRI KRiZi } \\
\hline 8. НÜКÜMET & & & \multirow{2}{*}{\multicolumn{2}{|c|}{1935 BULGARISTAN KRizi }} & \multirow{5}{*}{\multicolumn{2}{|c|}{1936 SANCAK KRiZi }} & & & & \\
\hline 9. НÜКÜMET & \multirow{2}{*}{ MAHMUT CELAL BAYAR } & \multirow{2}{*}{ CHP } & & & & & & & & \\
\hline 10. HÜKÜMET & & & & & & & & & & \\
\hline 11. НÜKÜMET & \multirow{2}{*}{ REFIK SAYDAM } & \multirow{2}{*}{ CHP } & & & & & & & & \\
\hline 12. HÜKÜMET & & & & & & & \multicolumn{4}{|c|}{1942 STRUMA KRizi } \\
\hline 14. НÜKÜMET & ŞÜKRU SARAÇOĞ́LU & СHP & \multirow{2}{*}{\multicolumn{3}{|c|}{1945 SOVYEt TALEPLERI KRIZi }} & & & & & \\
\hline 15. HÜKÜMET & MEHMET RECEP PEKER & CHP & & & & & & & & \\
\hline 21. HÜKÜMET & \multirow{3}{*}{ ADNAN MENDERES } & \multirow{3}{*}{ DP } & \multicolumn{3}{|c|}{ 6-7 EYLÜL 1955 OLAYLARI KRiZi } & & & & & \\
\hline 22. HÜKÜMET & & & \multirow{2}{*}{\multicolumn{3}{|c|}{1957 SURIYE KRIZi }} & \multirow{2}{*}{\multicolumn{5}{|c|}{1958 IRAK KRizi }} \\
\hline 23. HÜKÜMET & & & & & & & & & & \\
\hline 30. НÜКÜMET & \multirow{3}{*}{ SÜLEYMAN DEMIREL } & \multirow{3}{*}{ AP } & \multicolumn{2}{|c|}{1967 KIBRIS KRizi } & \multirow{3}{*}{\multicolumn{6}{|c|}{ 1968-1974 AFYON KRizi }} \\
\hline 31. HÜKÜMET & & & & & & & & & & \\
\hline 32. HÜKÜMET & & & & & & & & & & \\
\hline 45. HÜKÜMET & \multirow{2}{*}{ TURGUT ÖZAL } & pup & 1981 & 1984 LiMNi KRizi & 1984-1990 & \multirow{3}{*}{\multicolumn{3}{|c|}{1989 BULGARISTAN GÖÇÜ KRIZi }} & & \\
\hline 46. HÜKÜMET & & ANAPP & $1987 \mathrm{KI}$ & TA SAHANLIĞI KRiZi & $\begin{array}{l}\text { BATI } \\
\text { TRAKYA }\end{array}$ & & & & \multirow{2}{*}{\multicolumn{2}{|c|}{1988 -1991 IRAKLI SIĞINMACILAR KRIZi }} \\
\hline 47. HÜKÜMET & YILDIRIM AKBULUT & ANAP & & & KRizi & & & & & \\
\hline 48. HÜKÜMET & MESUT YLLMAZ & ANAP & & & & & & & & \\
\hline 58. НÜКÜMET & ABDULLAH GÜL & AKP & & & & & & & & \\
\hline 59. HÜKÜMET & & & & & & & & & & \\
\hline 60. HÜKÜMET & RECEP TAYYIP ERDOĞAN & AKP & 2003 DOĞU & 2003 SÜ̈ЕYMANIYE & & & & & & \\
\hline 61. HÜKÜMET & & & $\begin{array}{l}\text { AKDENiz } \\
\text { MEB KRizi }\end{array}$ & ÇUVAL KRIZi & MARMARA & & & & & \\
\hline 62. HÜКÜMET & AHMET DAVUTOĞLU & AKP & & & & KRizi & REHINE KRizi & $\begin{array}{l}2015 \text { SÜLEYMAN } \\
\text { SAH TÜRBESI KRiZi }\end{array}$ & & \\
\hline 63. HÜKÜMET & & & & & & & & & & \\
\hline 64. HÜKÜMET & & & & & & & & & $\begin{array}{l}2015 \text { SU-24 RUS } \\
\text { UČAGININ } \\
\text { DUsșüRüLMESi } \\
\text { KRiZi }\end{array}$ & $\begin{array}{l}2015 \text { BASSiKA } \\
\text { KRizi }\end{array}$ \\
\hline 65. HÜKÜMET & BINALI YILDIRIM & AKP & & & & & \begin{tabular}{|c|} 
2016- FIRAT \\
KALKANI \\
2016- FETÖ- \\
PDY \\
2017- R. \\
SARRAF/RAN'A \\
YAPTIRIMLAR \\
2017- PYD- \\
YPG-PKK \\
DESTEǴi \\
2018- ZEYTIN \\
DALI
\end{tabular} & & & \\
\hline
\end{tabular}

47 Bkz. Özdemir, Turgut Özal: Biyografi; Kemal Yamak, Gölgede Kalan İzler ve Gölgeleşen Bizler, İstanbul, Doğan Kitap, 2006; Engin Güner, Özal'lı Yillar, İstanbul, Doğan Kitap, 2003.

48 Bkz. Aksu, Türk Dış Politikasında Zorlayııı, s.173-174. 
Özal'ın Cumhurbaşkanlığında iki kriz öne çıkmaktadır. Bunlardan biri Ermenistan ile yaşanan Nahçıvan Krizi, diğeri ise Irak'in Kuveyt'i işgaliyle gelişen uluslararası krizdir. Ermenistan'la yaşanan Nahçıvan Krizi, Türkiye'yi de içine çekmeye başladığında Türkiye Nahçıvan'ın toprak bütünlüğünün korunması konusundaki antlaşmalardan kaynaklanan yükümlülüklerini gündeme getirmiştir. Ermenistan, Nahçıvan'da işgal ettiği bölgelerden geri çekilmediği takdirde askeri yöntemlere başvurabileceğini belirterek sınıra kuvvet yığmıştır. Bu durum Azerbaycan-Ermenistan savaşının bölgeye yayılması riskini arttırdığından üçüncü aktörlerin katkısıyla Ermenistan’ın işgali sonlandırması sağlanarak kriz atlatılabilmiştir. Askeri müdahale olasılığındaki artışla beraber Türkiye'de hükümete yönelik sert tartışmalar yaşanmış, bu durum sonraki koalisyon hükümeti döneminde de sürmüştür. ${ }^{49}$

Özal, cumhurbaşkanlığı döneminde dış politika sürecinin dışında kalmamaya çalışmıştır. ${ }^{50}$ Özellikle Irak'ın Kuveyt'e saldırmasının ardından başlayan uluslararası krizde Türkiye'nin Irak'ın saldırgan siyasetini kınaması ve BM yaptırım kararlarına katılması, hatta Irak’a karşı yapılacak çok uluslu koalisyon harekâtına aktif olarak katılmak istemesi Cumhurbaşkanı Özal ile hükümet arasında görüş ayrılığı doğurmuştur. Irak’a yönelik harekâtın kuzeyden Türkiye üzerinden yapılması konusunda Özal'ın askeri-siyasi karar sürecinde tartışılan görüşlerden daha radikal görüşler ifade etmesi Türkiye’nin siyasal yaşantısında tartışmalara neden olmuştur. Bu süreçte Genelkurmay Başkanı Necip Torumtay, Dışişleri Bakanı Ali Bozer, Savunma Bakanı Sefa Giray istifa ederek Cumhurbaşkanı ve Bakanlar Kurulu arasında çıkan görüş ayrılıklarında özgün bir siyasal davranış sergilemiştir. Başbakan Yıldırım Akbulut'un da Cumhurbaşkanı Özal'ın Bakanlar Kurulu'nun kararlarına müdahalesinden şikâyetçi olduğu ve Özal’a direndiği anlaşılmaktadır. ${ }^{51}$

Çoğunluk hükümeti olarak ikinci özgün örnek ise Adalet ve Kalkınma Partisi hükümetleridir. Tablo 6’da görüleceği gibi Kasım 2002 seçimlerinden günümüze devam eden Adalet ve Kalkınma Partisi hükümetleri döneminde 2015 yılına değin 6 önemli dış politika krizi ortaya çıkmıştır. Söz konusu dönemdeki krizler birçok açıdan özgün krizler olarak kabul edilebilir. Süleymaniye Çuval Krizi, Doğu Akdeniz MEB Krizi, Mavi Marmara Krizi, Suriye [RF-4] Krizi, IŞİD Rehineler Krizi, Süleyman Şah Türbesi krizleri dolayısıyla Türkiye bir yandan Ortadoğu sorunlarının bir parçası haline gelmiş, diğer yandan ise dış politika krizlerinde devlet-dışı aktörleri de dikkate almak zorunda kalmıştır. Bu dönemdeki dış politika krizlerinin bazıları "uyutulmuş" krizler olmakla birlikte halen önemli bir kısmı gelişmekte olan kriz niteliğindedir. Bu dönemde gerçekleşen Musul'daki Türkiye Başkonsolosluğu çalışanlarının rehin alınmasıyla ortaya çıkan kriz "rehine kurtarma pazarlıkları" şeklinde yürütülmüş ve resmi olmayan veya yarı resmi yol yöntemlerle rehinelerin can güvenliği ön planda tutularak başarıyla sonlandırılabilmiştir. ${ }^{52} \mathrm{Bu}$ olay sonrasında Türkiye IŞi̇D’in Suriye'deki faaliyetlerine karşı siyasasını değiştirmiştir.

Bu dönemde dış politika karar sürecinin nasıl işlediği tartışmalıdır. Başbakan olmadan önce başdanışman olarak Adalet ve Kalkınma Partisi hükümetlerinin dış politika kararlarında etkili olduğu

49 Bilal Şimşir, Azerbaycan: Azerbaycan'ın Yeniden Doğuş Sürecinde Türkiye-Azerbaycan İlişkileri, Ankara, Bilgi Yayınevi, 2011, s.414-422.

50 Özdemir, Turgut Özal: Biyografi.

51 Ibid.

52 Burada başarıdan kasıt rehinelerin can kaybına uğramadan Türkiye’ye getirilmiş olmasıdır. Karşıllı̆ında ne tür pazarlıkların yapıldığı ise ayrı bir tartışma konusudur. Bkz. Ayşe Küçük, "Non-State Actors in Turkish Foreign Policy Crises”, Fuat Aksu ve Helin Sarı Ertem (der.), Analyzing Foreign Policy Crises in Turkey: Conceptual, Theoretical and Practical Discussions, Cambridge, Cambridge Scholars Publishing, 2017, s.216-222. 
bilinen Ahmet Davutoğlu zaman içerisinde önce dışişleri bakanı olarak hükümetin içerisinde yer almış Recep Tayyip Erdoğan'ın cumhurbaşkanı seçilmesinin ardından da Adalet ve Kalkınma Partisi'nin başına geçerek başbakan olmuştur. Dolayısıyla dış politika kararlarının siyasal sorumluluğunu bu kez başbakan olarak üstlenmiştir. Ancak Davutoğlu’nun siyasi sorumluluğu üstlenmiş olmasına karşın Cumhurbaşkanı Erdoğan'ın kararlardaki etkisi sürmüştür. ${ }^{53}$

$\mathrm{Bu}$ dönemin genel işleyişi içerisinde dış ve güvenlik politikaları kararlarının alınması ve uygulanmasında askeri seçenekler 1990'lı yıllara göre daha az dillendirilse de 2010 sonrasında askeri seçenekler yeniden gündeme girmiştir. Ayrıca dikkat çekici olguysa bu dönemde kamu bürokrasisi açısından dış ve güvenlik kararlarının alınmasında ve uygulanmasında ad hoc bir yapılanmaya gidilmiş, Milli İstihbarat Teşkilatı́nın rolü belirginleşmiştir. ${ }^{54} \mathrm{Bu}$ bağlamda, dış politika öncelikleri bakımından tarihsel, kültürel, duygusal-insani-moral değerlerin sıklıkla dillendirilmiş olduğu bir dış politika tercihiyle lider özellikleri çerçevesinde tanımlanan bir dış politika pratiğinin işletilmiştir.

\section{Koalisyon Hükümetleri ve Dış Politika Krizleri}

Karar biriminin birden fazla koalisyon ortağının katılımıyla oluşması karar sürecinin işleyişi açısından kendine has zorluklar doğurur. ${ }^{55} \mathrm{Bu}$ durumda koalisyon ortaklarından hiçbiri koalisyon ortaklarının desteğini kazanmadan karar alamaz. Herhangi bir koalisyon ortağı karar sürecini istediği zaman işlemez hale getirebilir. ${ }^{56}$ Koalisyon hükümetlerinin kuruluşunda asgari bir mutabakat sağlanmış olsa da hükümet kurulduktan sonraki evrelerde koalisyon ortakları arasında ciddi görüş ayrılıkları ortaya çıkabilmektedir. ${ }^{57}$ Özellikle Bakanlar Kurulu'nun işleyişi bakımından hükümet ortaklarının dış politika öncelikleri çatışabilmekte, kriz durumlarında kararlar oluşturulurken müzakerelerin yerini pazarlık almaktadır. Bazı dış politika krizlerinde pazarlıkların kriz yönetimini zorlaştırmış olduğu

53 Rusya ile yaşanan SU-24 uçağının düşürülmesine ilişkin krizde düşürülen Rus uçağına ateş emrinin nasıl verildiği tartışılırken uçağı düşüren pilotların FETÖ/PDY bağlantısı ileri sürülmüştür. Dönemin Başbakanı olarak açıklama yapan Davutoğlu, daha önce verilen emir ve angajman kuralları gereği söz konusu uçağın düşürüldüğünü, uçağın düşürülmesine ilişkin emrin anlık değil, önceden kendisinin vermiş olduğu talimatlara dayandığını belirtmiştir. Böylece siyasi sorumluluğun kendisinde olduğunu vurgulamıştır. Bkz. "Davutoğlu’ndan Darbe Komisyonu'na 71 Sayfalık Yanıt”, http://im.haberturk.com/images/others/2017/01/12/Sayn_Davutoglu_Cevaplar.pdf, (Erişim Tarihi 4 Eylül 2018). Suriye Krizi sırasında Erdoğan ve Davutoğlu'nun liderlik özellikleri ve inançlarının krize ilişkin kararlara yansıması konusunda bkz. Helin Sarı Ertem, "Reflections of Beliefs and Worldviews of the Turkish Ruling Elite on the Syria Crisis", Aksu ve Ertem (der.), Analyzing Foreign Policy Crises in Turkey, s.112-142.

542014 ve 2017 yılında Devlet İstihbarat Hizmetleri ve Milli İstihbarat Teşkilatı Kanunu’nda gerçekleştirilen değişiklikler ve eklenen yeni görev, yetki ve sorumluluklardan bir kısmı bu kapsamda değerlendirilebilir. Ayrıntılar için bkz. https:// www.mit.gov.tr/text_site/2937.pdf, (Erişim Tarihi 4 Eylül 2018).

55 Hermann ve Hermann, "Who Makes Foreign", s.367.

56 Bkz. Joe D. Hagan, Philip P. Everts, Haruhiro Fukui, John D. Stempel, "Foreign Policy by Coalition: Deadlock, Compromise, and Anarchy”, International Studies Review, Cilt 3, No.2, 2001, s.169-216.

571963 Kıbrıs olayları sırasında hükümeti oluşturan CHP-YTP-CKMP-Bağımsızlar koalisyonu iç siyasi çekişmeler dolayısıyla kritik bir süreçte dağılmış, hükümet krizi ile Kıbrıs krizi eş zamanlı yürütülmek zorunda kalmıştır. 23 Aralık 1963 'te İnönü’nün Başbakanlığında bağımsız milletvekillerinin de desteği ile oluşturulan 28. hükümet döneminde 1964 Kıbrıs krizi yönetilmiştir. Hükümetin güvenoyu alması sırasında CHP’nin tek başına yeter oya sahip olmaması dolayısıyla güven oylamasına dönüşen hükümet programının kabulünde bağımsızların desteği ve Yeni Türkiye Partisi'nin hükümeti dışarıdan desteklemesi ile hükümet kurulabilmiştir. Kıbrıs krizi sürerken Türkiye'nin bir hükümet krizi yaşamasının sakıncaları dillendirilerek bir dayanışma duygusu yaratılmış olsa da hükümete verilen destek kritik zamanda çekilerek bütçe oylamalarında hükümetin düşmesi gerçekleşmiştir. 12 Şubat 1964'te İnönü’nün istifası ile hükümet yeni hükümet kuruluncaya değin azınlık hükümeti olarak görev yapmak ve Kıbrıs krizini yönetmek zorunda kalmıştır. Başbakan İnönü Johnson Mektubu sonrasında Haziran ayında Washington'a giderken Meclis'te desteğini yitirmiş, bütçesi reddedilmiş bir hükümet başkanı durumunda kalmıştır. Suat Hayri Ürgüplü’nün başbakanlığında yeni hükümet ise ancak 4 Mart 1965 'te kurulabilmiştir. 
da görülmektedir. Tablo 8'de Türkiye'de koalisyon hükümetleri döneminde yönetilen dış politika krizlerini dağılımı görülmektedir. 1974 Kıbrıs krizinde Cumhuriyet Halk Partisi (CHP) ile Milli Selamet Partisi'nin (MSP) kurduğu koalisyon hükümetinde Kıbrıs’a yapılacak askeri harekâtın niteliği ve sınırları konusunda ciddi görüş ayrılıklarının olduğu anlaşılmaktadır. Bu görüş ayrılıkları ateşkes ve Cenevre görüşmeleri sırasında da sürmüş, harekâtın ikinci evresinden sonra ateşkes kabul edildiğinde de hükümetin bozulmasında rol oynamıştır. Harekâtın birinci evresinde Bakanlar Kurulu’nda ateşkese karar verilmesi aşamasında usul olmamasına karşın oylama yapılmıştır. MSP kanadı sonuçtan memnun olmayınca Başbakan Ecevit ve Başbakan Yardımcısı Erbakan Genelkurmay Başkanlığı'na giderek Genelkurmay Başkanı Orgeneral Semih Sancar'dan kapsamlı brifing almıştır. Ancak bundan sonra Bakanlar Kurulu’nda ateşkese karar vermek mümkün olmuştur.

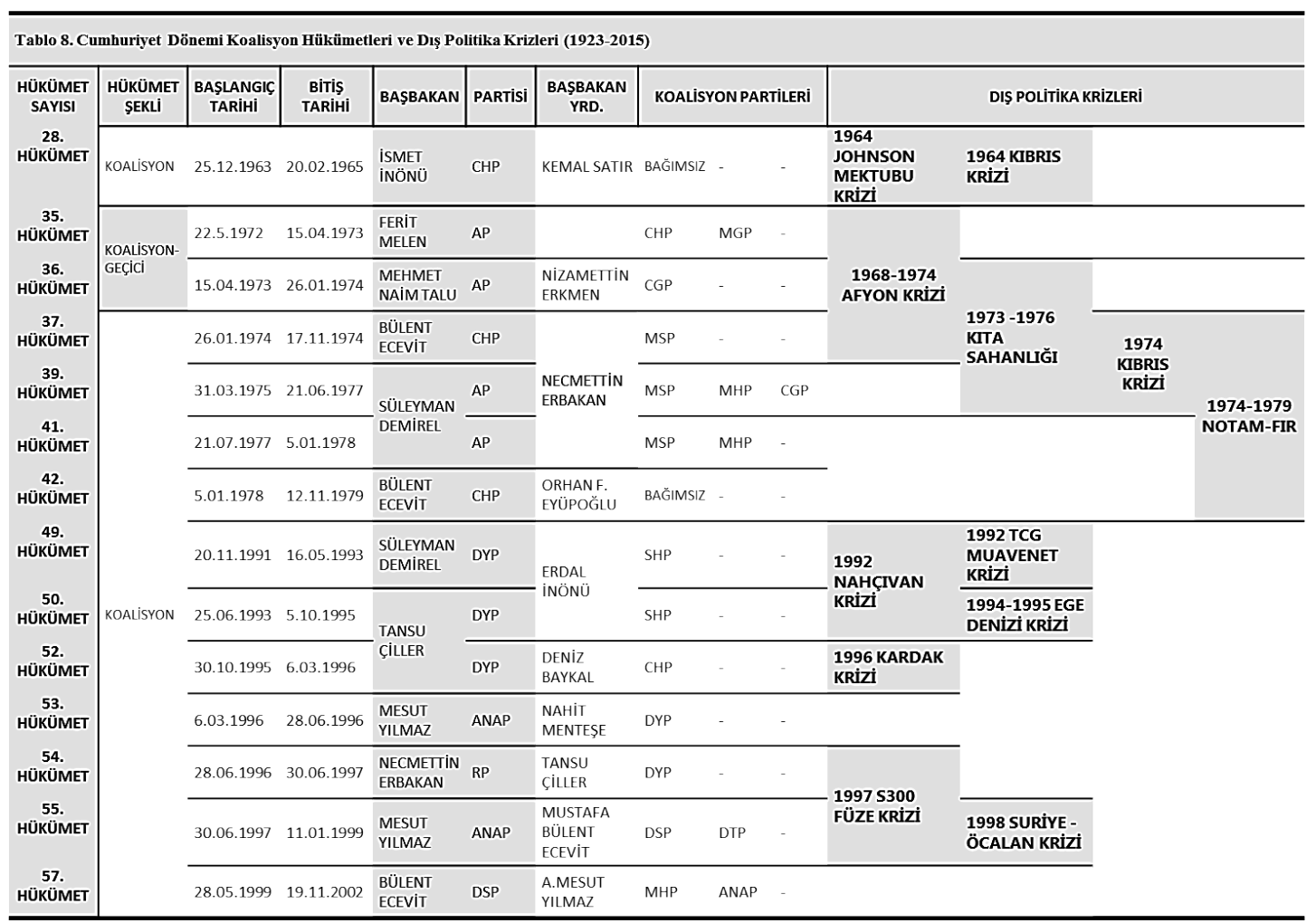

Soğuk Savaş ardılı dönemde kurulan koalisyon hükümetlerinin yönettiği dış politika krizleri içerisinde 1992 Nahçıvan Krizi, 1992 TCG Muavenet Krizi, 1996 Kardak Krizi ve 1998 SuriyeÖcalan Krizi özellikle çarpıcıdır. Nahçıvan Krizi sırasında Türkiye’nin ahdi yükümlülükleri TürkiyeErmenistan arasında sıcak çatışma riski doğurduğunda askeri bir müdahalenin yaratacağı sorunlarla ulusal kamuoyunun baskısı arasında kalan bir hükümet görüntüsü ortaya çıkmıştır. ${ }^{58}$ Krizi yöneten Başbakan Demirel mevcut uluslararası koşullarda Nahçıvan Krizi’ne askeri müdahaleyle çözüm üretmenin Türkiye'yi SSCB/Rusya Federasyonu'yla karşı karşıya getirebileceğini dikkate almış ve diplomatik-siyasi çözümden yana olmuştur.

58 Nahçıvan Krizi’nde ahdi hukuk-kriz yönetimi ilişkisi için bkz. Fuat Aksu ve Yunus Çolak, “Türkiye’nin Dış Politika Krizlerinde Ahdi Hukuk: Kıbrıs ve Nahçıvan Krizleri”, Bilig (Yayın Sürecinde). 
1992 yılındaki TCG Muavenet gemisinin vurulması olayında ise Türkiye-ABD arasındaki ilişkilerin seyrini önemli ölçüde etkileyen bir gelişme olarak değerlendirilmesine rağmen krizin uyutulması tercih edilmiştir. Uluslararası sistemde bir geçiş/değişim yaşanırken büyük müttefik $\mathrm{ABD}$ ile karşı karşıya gelmek rasyonel bulunmamıştır. Her iki krizde koalisyon ortakları (DYP-SHP) birlikte hareket etmiştir. DYP-SHP (CHP) arasındaki bu uyumluluk Kardak Krizi sırasında da sürmüştür. $\mathrm{Bu}$ krizde koalisyon ortakları arasında görüş ayrılı̆̆ından daha belirgin olan nokta Cumhurbaşkanı Demirel ile Başbakan Çiller arasındaki görüş ayrılığıdır. İki lider arasında krizin niteliği ve hangi araçyöntemlerle yönetileceğine dair önemli görüş ayrılıkları ortaya çıksa da bu görüş ayrılıkları giderilerek Cumhurbaşkanı Demirel'in önerdiği stratejiler izlenmiş, kriz sıcak bir çatışmaya dönüşmeden atlatılmıştır. ${ }^{59}$

1998 Suriye-Öcalan Krizi’nde ise Cumhurbaşkanı Demirel'in partiler-üstü kimlikle karar süreci içerisinde yer aldığı görülür. Bu krizin seyri içerisinde ANAP lideri Mesut Yılmaz’ın başbakanlığında ANAP-DTP-DSP üçlü koalisyon hükümeti görev yapmıştır. Krizde Demirel, cumhurbaşkanı olarak baskın lider görüntüsündedir. Suriye-Öcalan Krizi Türk siyasi tarihi açısından önemli bir dönüm noktasını oluşturması ve koalisyon ortakları arasındaki uyum bakımından dikkate değerdir. ${ }^{60}$

\section{Sonuç}

Türkiye'nin dış politika krizlerinde müdahil değişkenler bağlamında siyasal karar birimi ve hükümetlerin özellikleri krizlerindeki kararların oluşumunda belirgin bir biçimde etkilidir. Dış politika krizlerinin dönemsel incelenmesinden anlaşlacağı üzere Atatürk ve İnönü dönemi ayrı tutulursa çok partili demokratik dönemde siyasal karar birimi anayasal gerekliliğin sonucu olarak nihai kararların sorumluluğunu üstlenmiştir. Ancak özellikle başbakanken cumhurbaşkanlığına yükselen siyasetçilerin başbakanlık dönemlerindeki görev, yetki ve sorumluluklarını kullanmaya çalıştıklarında siyasal sorumlu ile siyasal sorumsuz aktörler arasında çatışma doğmaktadır. Bu bağlamda cumhurbaşkanlarının anayasal görev, yetki ve sorumluluklarının sınırlarını aşmadan görüşlerini ifade ettikleri durumlarda yürütme erkinin daha istikrarlı çalıştığı söylenebilir. 1961 Anayasası ile Türk siyasal hayatında önemli bir yer edinmiş bulunan Milli Güvenlik Kurulu’nda, Bakanlar Kurulu toplantılarında ve TBMM'de cumhurbaşkanının iç-dış gündeme dair açıklamalarıyla görüşlerini açıklaması görev ve sorumluluğu gereğidir. Özellikle dış politika krizlerinde cumhurbaşkanının yürütmenin siyasal sorumsuz kanadını oluşturduğunu unutarak doğrudan nihai karar birimi gibi süreci etkilemeye ve yönlendirmeye çalışması kriz yönetim süreçlerini zorlaştırmaktadır. Böylesi durumlarda Türkiye'deki karar biriminin iki başlı olduğu algısı ortaya çımaktadır. Cumhurbaşkanı Özal'ın Yıldırım Akbulut, Süleyman Demirel ve Mesut Yılmaz'in başbakanlıkları döneminde kararlara müdahalede bulunması, Cumhurbaşkanı Erdoğan'ın Ahmet Davutoğlu ve Binali Yıldırım'ın başbakanlıkları döneminde dış politika kararlarındaki baskın rolü bunun çarpıcı örnekleridir. Süleyman Demirel de başbakanlığının ardından cumhurbaşkanı seçildikten sonra zaman zaman iç ve dış politika alanında karar sürecinde baskın aktör olmuştur. Diğerlerinden görece farklı olarak Demirel'in cumhurbaşkanlığına seçildiği dönemde parlamentoda partisinin çoğunluk hükümeti oluşturamadığı görülmektedir. Dolayısıyla

59 Bkz. Cüneyt Arcayürek, 28 Şubat’a İlk Adım, Büyüklere Masallar Küçüklere Gerçekler Dizisi, Cilt 9, Ankara, Bilgi Yayınları, 2003; Nur Batur, Yürekten Gülerekten Yürüdüm, İstanbul, Doğan Kitap, 2004, s.30-32; Taner Baytok, Bir Asker Bir Diplomat, İstanbul, Doğan Kitapçlık, 2001, s.192.

60 Bkz. Rıdvan Akar ve Can Dündar, Ecevit ve Gizli Arşivi, Ankara, İmge Yayınları, 2008, s.406-432. 
cumhurbaşkanı seçildikten sonra Demirel partiler-üstü konum elde ederken istikrarsız hükümetlerin kriz durumlarındaki dış politika karar ve uygulamalarında anayasal görev, yetki, sorumluluk ve haklarını dengeli bir şekilde kullanmıştır. Demirel'in iç siyasete ilişkin müdahaleleri ise kimi zaman eski partisi içerisinde tartışmalara neden olmuştur.

Siyasi sorumluluk açısından hesap verebilirliği ve yetkileri sınırlı olan cumhurbaşkanının başbakanlarla çatışmasının sonucu olarak Cumhurbaşkanı Özal zaman zaman başkanlık-yarı başkanlık rejimine geçilmesi gerektiğine dair düşüncelere sahip olsa da bunu gerçekleştirmesi mümkün olmamıştır. Kriz durumlarında dış politikanın oluşturulmasında kendi görüşlerini Bakanlar Kurulu'na kabul ettirememiştir. Görüşlerinin hükümet tarafından dikkate alınmaması karşısında yeniden ANAP'ın başına geçerek aktif siyasete geri dönmeyi düşündüğü ancak ölümü ile bunu gerçekleştirmeye fırsatı olmadığı görülmektedir.

Yürütmenin koalisyon hükümetleri tarafından üstlenildiği durumlarda dış politika kararlarının oluşumu tartışma yaratabilmektedir. Çoğunluk hükümetlerinden farklı olarak koalisyon hükümetlerinde kurucu partilerin liderlerinin karar yapısı içerisindeki rolleri ve etkileri kararın niteliğine yansıyabilmektedir. Bu durum özellikle kriz durumlarında koalisyon ortakları arasında çeşitli pazarlıkları ortaya çıkartabilmekte, alınacak kararların ivediliğini ve tutarlılığını bozabilmektedir. 